\title{
Mechanisms of Psychostimulant-Induced Structural Plasticity
}

\author{
Sam A. Golden and Scott J. Russo \\ Department of Neuroscience and The Friedman Brain Institute, Mount Sinai School of Medicine, New York, \\ New York 10029 \\ Correspondence: scott.russo@mssm.edu
}

\begin{abstract}
Psychostimulants robustly induce alterations in neuronal structural plasticity throughout brain reward circuits. However, despite our extensive understanding of how these circuits modulate motivated behavior, it is still unclear whether structural plasticity within these regions drives pathological behavioral responses in addiction. Although these structural changes have been subjected to an exhaustive phenomenological characterization, we still have a limited understanding of the molecular mechanisms regulating their induction and the functional relevance of such changes in mediating addiction-like behavior. Here we have highlighted the known molecular pathways and intracellular signaling cascades that regulate psychostimulant-induced changes in neuronal morphology and synaptic restructuring, and we discuss them in the larger context of addiction behavior.
\end{abstract}

\begin{abstract}
Adiction is characterized by persistent drugAseeking behavior and a high frequency of relapse. The repercussions of such drug seeking and relapse behavior place a strong economic, social, and health burden on all levels of society. In fact, the World Drug Report estimates that $5 \%$ of the world's population use illicit drugs, placing a suggested socioeconomic burden of several hundred billion U.S. dollars annually (UNODC 2010). Unfortunately, there are still relatively few effective therapeutic interventions available for the treatment of substance abuse. This has led to a concerted effort to reveal the molecular and cellular basis of addiction (Hyman and Malenka 2001; Nestler 2001, 2004; Koob and Le Moal 2005; Hyman et al. 2006; Kauer and Malenka 2007; Kalivas 2009; Luscher and Malenka 2011; Wolf 2011),
\end{abstract}

to enable the development of novel pharmacotherapeutic agents and treatment strategies (Nestler 2002; O’Brien 2008; Wessell and Edwards 2010).

A defining hallmark of drug abuse is compulsive and persistent drug-seeking behavior at the expense of negative emotional, physical, and social consequences. This persistent behavior has led to the hypothesis that drugs of abuse have the capacity to provoke long-lasting changes to the brain, which underlie pervasive and uncontrolled addiction-related behavioral phenotypes. This is supported by findings that chronic exposure to all known addictive substances results in dramatically altered patterns of gene expression in key brain reward centers. Similarly, early investigations established that one of the more robust forms of neuronal

Editors: R. Christopher Pierce and Paul J. Kenny

Additional Perspectives on Addiction available at www.perspectivesinmedicine.org

Copyright (C) 2012 Cold Spring Harbor Laboratory Press; all rights reserved; doi: 10.1101/cshperspect.a011957

Cite this article as Cold Spring Harb Perspect Med 2012;2:a011957 
S.A. Golden and S.J. Russo

plasticity associated with repeated psychostimulant administration is a long-lasting restructuring of neuronal arbors and dendritic spines (Robinson and Kolb 1997) (for a description of dendritic spine morphology, see Box 1). It is now evident that brain reward pathwayscentered on dopaminergic projections from the ventral tegmental area (VTA) and glutamatergic projections from the prefrontal cortex (PFC), amygdala (Amy), and hippocampus (Hipp) to the nucleus accumbens (NAc) - are plastic and therefore undergo changes (Fig. 1). Despite an extensive literature detailing the various contributions of these circuits toward

\section{BOX 1. DENDRITIC SPINE MORPHOLOGY}

Psychostimulant-induced structural plasticity is generally characterized by three parameters: (1) dendritic spine density, (2) dendritic spine size and shape (morphology), and (3) dendritic arborization or complexity. Recent advances in methodology have greatly increased our ability to identify more discrete and subtle changes in dendritic spine morphology. Rather than simply measuring spine density, these tools allow for the characterization of dendritic spines by type (i.e., thin, mushroom, or stubby) or volume, which more accurately reflects the functional relevance of experiencedependent plasticity (Petrak et al. 2005; Holtmaat and Svoboda 2009). Furthermore, synaptic activity at individual dendritic spines is directly coupled to structural reorganization (Matsuzaki et al. 2004). (A) A three-dimensional re-creation of a Lucifer yellow (LY) filled dendritic segment from a medium spiny neuron (MSN) located in the NAc. As can be easily observed, there is a large dynamic continuum along which dendritic spine morphology falls. (B) Stubby spines, or spines whose total length is nearly equal to their spine head diameter, are the least well understood. They are most prominent during development and are generally considered to be immature and plastic synaptic elements, while also strongly coupled to their parent dendrite (Schmidt and Eilers 2009). This
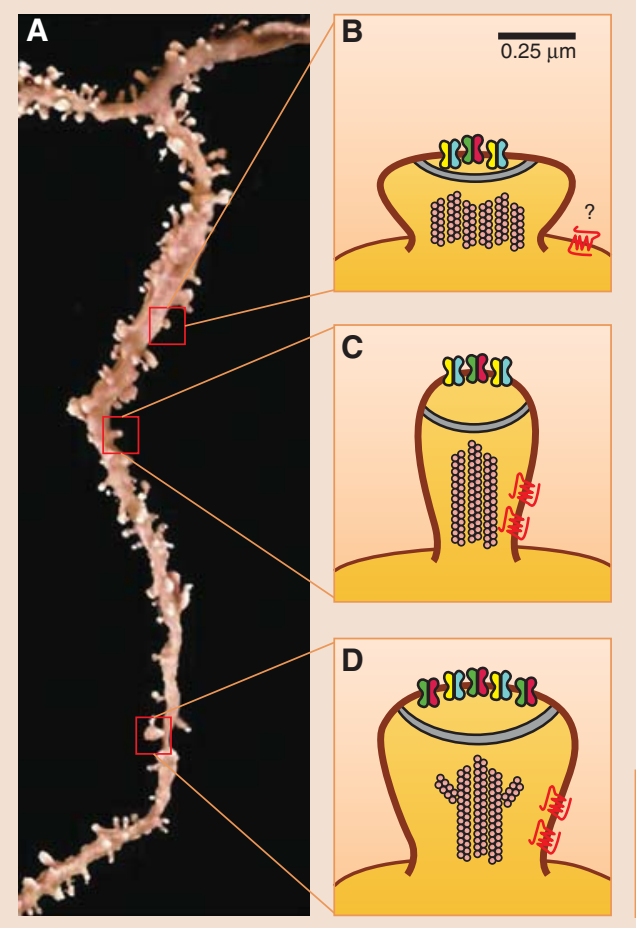
strong coupling suggests that changes in frequency of stubby spines may disproportionally impact neuronal excitability relative to other spine types (Noguchi et al. 2005). Furthermore, the lack of a spine neck is believed to preclude direct innervations by inhibitory connections. It is critical to point out that most common methods for assessing spine morphology (i.e., Golgi-Cox stain) are unable to detect stubby spines reliably. (C) Thin spines, whose total length is greater than their

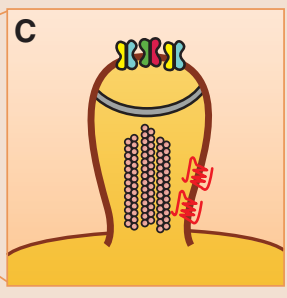
head width and head width is greater than their neck width, are also considered to be immature, plastic elements. (D) Mushroom spines, whose head width is greater than their neck width, are considered to be the most stable and nonplastic spine types along the continuum. Mushroom spines also show increased AMPAR frequency along the postsynaptic density (PSD), relative

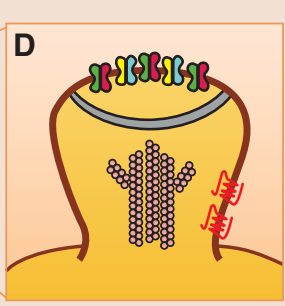
to stubby spines. Owing to their differential physiological properties, these kinds of detailed morphological assessments of

$\mathscr{B}$ AMPA receptors

$£$ NMDA receptors

D1/D2 receptors O Actin monomer spines are more accurate than total spine density. (Panel $A$ is modified, with permission, from Russo et al. 2010.) 
motivated behavior, it is still unclear to what extent dendritic spine plasticity drives the pathological behavior evident in addiction. Likewise, the exhaustive phenomenological characterizations of psychostimulant-induced structural plasticity have not translated into a detailed mechanistic understanding of such plasticity.

Recently, there have been a few studies identifying more causal gene regulatory networks that drive structural plasticity to control addiction behavior. Intriguingly, the temporal patterns of drug-induced gene expression changes are very transient and do not fully explain the long-lived alterations in addiction-related behavior. Rather, it is thought that regulation of biochemical and molecular signals, induced during early phases of drug administration in vulnerable populations, facilitates the transition to addiction by inducing more permanent morphological and functional alterations to neuronal populations that control addictive behaviors. Evidence points toward unique epigenetic and transcriptional mechanisms by which cocaine modulates posttranslational histone architecture at the fos $B$ promoter to enhance expression of the transcription factor $\Delta$ FosB. This results in direct regulation of downstream transcriptional targets such as nuclear factor-

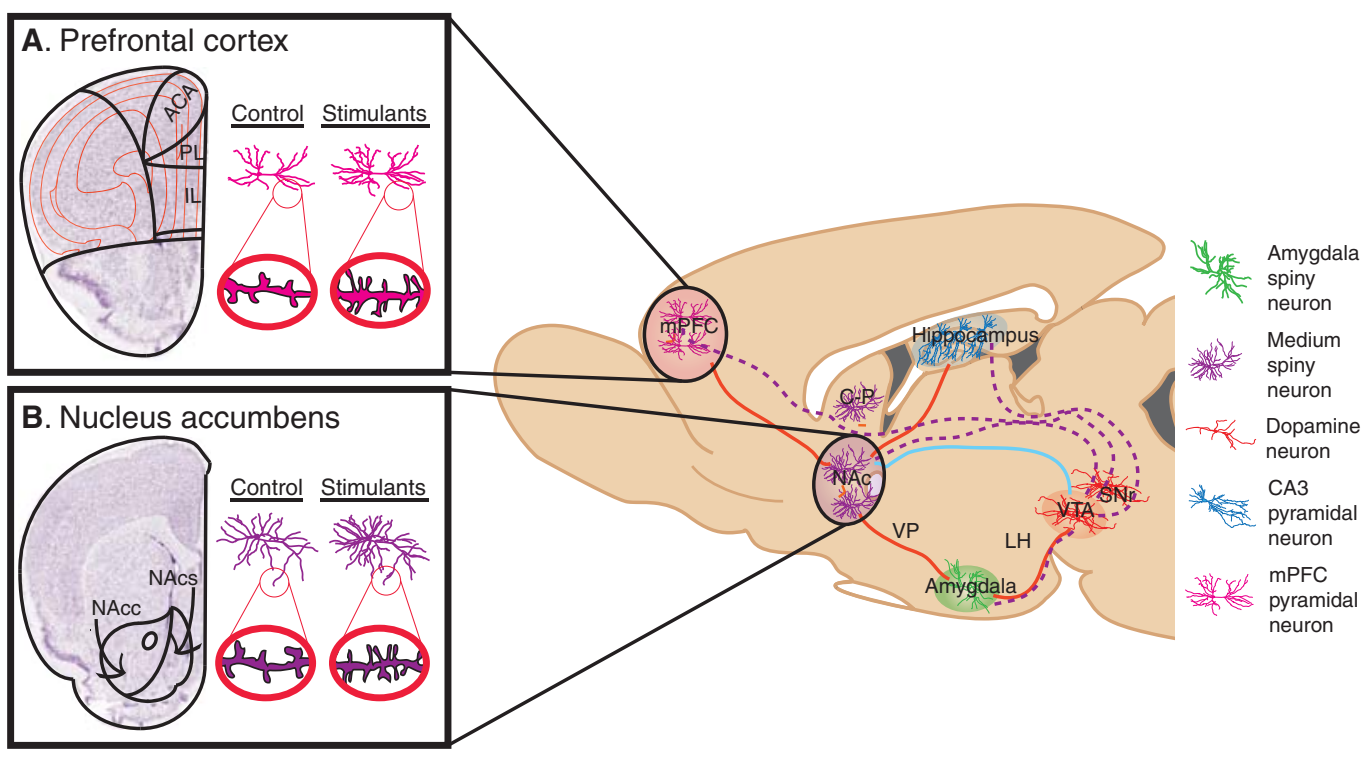

Figure 1. Neural circuitry implicated in reward and underlying addiction. Several brain regions are directly involved in modulating reward and are associated with the pathology of substance abuse disorders. Dopaminergic VTA projection neurons (dotted purple lines) innervate the NAc and mPFC, as well as the hippocampus and amygdala. GABAergic afferents from the NAc (some direct and some indirect) (solid blue line) provide inhibitory feedback to dopaminergic VTA neurons. Excitory glutamatergic afferents (solid red lines) project to the NAc from the mPFC, hippocampus, and amygdala, as well as glutamatergic innervation of the VTA by the amygdala and hippocampus. Each region contains specialized cell types believed to play crucial roles in both natural reward phenomena and addiction-related phenotypes. These cell types, color-coded in the key, include amygdala (green) and NAc (purple) medium spiny neurons, mPFC (pink) and hippocampal CA3 (blue) pyramidal neurons, and VTA dopamine neurons (orange). Not shown are serotonergic projections from the DR and noradrenergic projections from the LC. Psychostimulants, as well as other drugs of abuse, robustly modulate the structural plasticity of individual neurons within these regions. Nissl-stained coronal sections of the $(A) \mathrm{mPFC}$, and $(B) \mathrm{NAc}$, with the left hemisphere of each marked schematically to represent subregions of interest. mPFC, Medial prefrontal cortex; NAc, nucleus accumbens; C-P, caudate-putamen; VP, ventral pallidum; LH, lateral hypothalamus; VTA, ventral tegmental area; SNr, substantia nigra; DR, dorsal raphe; LC, locus coeruleus; ACA, anterior cingulated; PL, prelimbic cortex; IL, infralimbic cortex; NAcc, nucleus accumbens core; NAcs, nucleus accumbens shell. (Adapted, with permission, from Russo et al. 2009.) 
$\kappa \mathrm{B}(\mathrm{NF \kappa B})$, cyclin-dependent kinase ( $\mathrm{Cdk} 5)$, and myocyte enhancing factor 2 (MEF2), consequentially leading to various alterations in structural plasticity through several intracellular mechanisms that modulate cytoskeletal remodeling. In this article, we describe these molecular findings in the greater context of structural plasticity and explore their physiological relevance to drug addiction, and then highlight key areas for future investigation.

\section{BASIC NEUROANATOMY OF REWARD CIRCUITRY}

The neurobiological substrates modulating natural reward learning and motivated behavior are some of the most evolutionarily conserved in the mammalian brain and function to direct our resources toward procuring food and reproduction (Walker et al. 1996). Drugs of abuse such as amphetamine and cocaine usurp this basic function, essentially hijacking the circuitry via induction of maladaptive plasticity (Kauer and Malenka 2007; Kalivas et al. 2009; Chen et al. 2010; Russo et al. 2010; Van den Oever et al. 2010; Badiani et al. 2011; Luscher and Malenka 2011; Sulzer 2011). As mentioned above, the dopaminergic mesolimbic pathway and its associated neuroanatomical structures are heavily implicated in drug-induced neuropathology (Fig. 1). Dopaminergic afferents project from the VTA and release dopamine on MSNs in the NAc, as well as limbic and cortical regions such as the amygdala and prefrontal cortex, respectively. Other monoaminergic nuclei, including serotonergic projections from the dorsal raphe (DR) and noradrenergic projections from the locus coeruleus (LC), exert profound influence over reward-related behavior. Similarly, a number of glutamatergic nuclei also innervate the NAc, including the medial PFC (mPFC), orbital PFC (oPFC), anterior cingulate cortex (ACC), hippocampus, amygdala, and thalamus. Although psychostimulants have been shown to induce plasticity throughout most of these regions, the ensuing sections focus primarily on the prefrontal cortical regions and limbic accumbal regions because the majority of currently available data originates from these brain structures.

The PFC is commonly broken into two major subsections - the mPFC and oPFC - that have unique patterns of connectivity and behavioral control depending on the cortical layers and cell types being examined (Fig. 1B) (Ongur and Price 2000; Dalley et al. 2004). To date, morphological changes have only been identified in glutamatergic pyramidal neurons, despite the fact that there is a significant population of GABAergic interneurons in these cortical structures. Future studies are needed to examine whether there are any stimulant-induced changes in dendritic branching or size, because these neurons do not contain specialized spine structures.

The NAc consists of two anatomically distinct structures, the core and shell regions (Jongen-Relo et al. 1993, 1994), which receive differential afferent innervation (Brog et al. 1993) and project to separate neuroanatomical structures (Fig. 1A) (Heimer et al. 1991). Not surprisingly, cocaine and amphetamine regulate synaptic, structural, and behavioral plasticity differentially between the core and shell subregions (Kourrich and Thomas 2009; Dumitriu et al. 2012). This remarkable diversity of neuroanatomical and structural complexity is further layered in the NAc by multiple neuronal cell types, primarily identified as either MSNs expressing Drd1 (MSN-Drd1) or Drd2 (MSNDrd2) receptors, aspiny cholinergic interneurons, or GABAergic interneurons. The Drd1and Drd2-expressing MSNs are estimated to constitute $>95 \%$ of the total striatal neuronal population. These MSNs are supplemented by a much smaller and sparsely distributed population of aspiny cholinergic interneurons believed to be $<1 \%$ of the total striatal neuronal population (Rymar et al. 2004), which have also been identified as expressing Drd2 mRNA (Le Moine et al. 1990).

Lastly, there are three distinct GABAergic interneuron populations (Kawaguchi et al. 1995; Tepper et al. 2010), which do not express either Drd 1 or Drd 2 receptors (Bertran-Gonzalez et al. 2008) and are believed to make up 3\% of all striatal neurons (Rymar et al. 2004). This 
neuronal complexity has vastly inhibited progress. It has only been in the last several years that cell-type specificity has been accounted for in structural studies, and still greater specificity is needed. There is also a need to expand our understanding of structural plasticity within cell types outside of the PFC and NAc, which have received the majority of scientific scrutiny. In the following subsections, we synthesize this constantly evolving literature and identify areas for future investigation.

\section{STRUCTURAL PLASTICITY IN THE PREFRONTAL CORTEX}

In general, results from rodent studies have consistently shown that psychostimulants increase dendritic spine density in glutamatergic cortical pyramidal neurons of the mPFC (see Table 1 for references and summary). It is worth mentioning that nonhuman primate studies using Rhesus macaques show that both experimenteradministered and self-administered amphetamine significantly decreased mPFC dendritic spine density (Selemon et al. 2007; Coutinho et al. 2008). This dichotomy is interesting, although significant differences exist between the drug regimens and withdrawal period between these species-divergent studies and warrant further investigation (Table 1). Data are less conclusive when the oPFC is examined, finding that both self-administered and experimenter-administered amphetamine or cocaine can either decrease dendritic spine density (Crombag et al. 2005; Singer et al. 2009) or induce no change at all (Ferrario et al. 2005). Although data on dendritic arborization and complexity are less readily available, they are in agreement with the dendritic spine density data showing increased arborization and complexity (Robinson and Kolb 2004).

To the best of our knowledge, all psychostimulant-induced structural plasticity within the cortex has been examined by Golgi-Cox stain, which is now considered a low-resolution methodology for structural analysis. New higher-fidelity methods described in Box 2, such as DiI or Lucifer yellow filling, may allow for a more detailed cell-type-specific understanding of PFC structural dendritic spine dynamics. To date, work has focused exclusively on glutamate pyramidal cells, and it is unclear whether GABAergic interneurons undergo similar structural plasticity. Lastly, the PFC is potentially located close enough to the brain surface for successful two-photon live imaging experiments in animals over time (Box 2). These types of longitudinal assessments of spine plasticity could give us an unprecedented understanding of how spines form and retract during the many complex phases of addiction and greatly enhance our understanding of structural plasticity in addiction.

\section{STRUCTURAL PLASTICITY IN THE NUCLEUS ACCUMBENS}

The majority of data available on psychostimulant-induced structural plasticity are from analysis of MSNs in the NAc. Historically, when assessed by Golgi-Cox stain, both amphetamine and cocaine induce robust increases in dendritic spine density and dendritic branching in the NAc core and shell (for references and summary, see Table 1) (Robinson and Kolb 2004). Recent advances in transgenic technology have allowed us to examine detailed cell-type-specific morphology of Drd1 - and Drd2-receptor-expressing MSNs in the NAc core and shell. Some studies have identified robust restructuring of only Drd1-MSNs within several days of repeated psychostimulant administration, both throughout the NAc core and shell (Dobi et al. 2011) and in the shell specifically (Kim et al. 2011). Conversely, others have found that cocaine causes an initial increase in dendritic spine density on MSNs in both the core and shell, but only dendritic alterations on the Drd1-receptorexpressing MSNs are shown to persist 1 mo later (Lee et al. 2006). This theme, that Drd1-MSN alterations are more common and possibly persistent following psychostimulant administration, has been observed in other forms of plasticity and may present an important and selective feature of addiction neurophysiology (Lobo et al. 2010; Lobo and Nestler 2011). Similarly, although there is no clear consensus, a general trend has become apparent whereby 


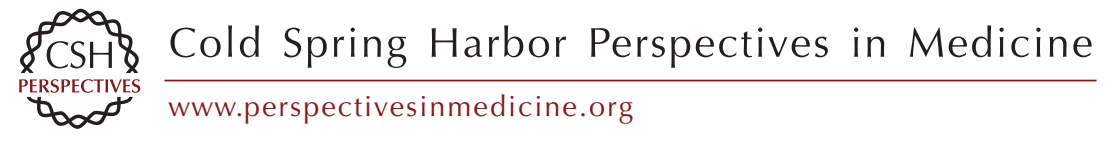

Table 1. Review of recent findings on psychostimulant-induced structural plasticity in the PFC and NAc

\begin{tabular}{|c|c|c|c|c|c|c|c|c|}
\hline References & Species & Gender & Drug & Route (dose) & Withdrawal & Method & Location & Result \\
\hline \multicolumn{9}{|c|}{ Prefrontal cortex } \\
\hline Crombag et al. 2005 & $\begin{array}{l}\text { Rat, SD } \\
\text { adult }\end{array}$ & Male & Amphetamine & $\begin{array}{l}\text { SA (0.125 mg/infusion) } \\
\quad 2 \mathrm{~h} / \mathrm{d}, 2-3 \mathrm{wk}\end{array}$ & $28 \mathrm{~d}$ & $\begin{array}{l}\text { Golgi } \\
(2 \mathrm{D})\end{array}$ & $\begin{array}{l}\text { mPFC } \\
\text { oPFC }\end{array}$ & $\begin{array}{l}\text { Increased spine density } \\
\text { Decreased spine density }\end{array}$ \\
\hline \multirow[t]{2}{*}{ Ferrario et al. 2005} & $\begin{array}{l}\text { Rat, Wistar } \\
\text { adult }\end{array}$ & Male & Cocaine & $\begin{array}{l}\text { SA }(0.4 \mathrm{mg} / \mathrm{kg} \text { per } \\
\text { infusion) } \\
\quad 1 \mathrm{~h} / \mathrm{d}, 6 \mathrm{~d} / \mathrm{wk}, 3 \mathrm{wk}\end{array}$ & $28 \mathrm{~d}$ & $\begin{array}{l}\text { Golgi } \\
(2 \mathrm{D})\end{array}$ & $\begin{array}{l}\text { mPFC } \\
\text { oPFC }\end{array}$ & $\begin{array}{l}\text { Increased spine density } \\
\text { No change }\end{array}$ \\
\hline & & & Cocaine & $\begin{array}{l}\mathrm{SA}(0.4 \mathrm{mg} / \mathrm{kg} \text { in } 50 \mu \mathrm{L} / \\
\text { infusion) } \\
\quad 6 \mathrm{~h} / \mathrm{d}, 6 \mathrm{~d} / \mathrm{wk}, 3 \mathrm{wk}\end{array}$ & $28 \mathrm{~d}$ & $\begin{array}{l}\text { Golgi } \\
(2 \mathrm{D})\end{array}$ & $\begin{array}{l}\mathrm{mPFC} \\
\mathrm{oPFC}\end{array}$ & $\begin{array}{l}\text { Increased spine density } \\
\text { No change }\end{array}$ \\
\hline Selemon et al. 2007 & $\begin{array}{l}\text { Rhesus } \\
\text { young } \\
\text { adult }\end{array}$ & Mixed & Amphetamine & $\begin{array}{l}\text { IM (escalating, } 0.1- \\
1.0 \mathrm{mg} / \mathrm{kg} \text { ) } \\
5 \mathrm{~d} / \mathrm{wk}, 6 \mathrm{wk}\end{array}$ & $3-3.5 \mathrm{yr}$ & $\begin{array}{l}\text { Golgi } \\
(2 \mathrm{D})\end{array}$ & $\begin{array}{l}\text { mPFC } \\
\text { oPFC }\end{array}$ & $\begin{array}{l}\text { Decreased spine density } \\
\text { - }\end{array}$ \\
\hline Coutinho et al. 2008 & $\begin{array}{l}\text { Rhesus } \\
\text { age not } \\
\text { stated }\end{array}$ & $\begin{array}{l}\text { Not } \\
\text { stated }\end{array}$ & Amphetamine & $\begin{array}{l}\text { SA }(0.75 \mathrm{mg} / \mathrm{kg} \text { per } \\
\quad \text { infusion }) \\
\quad 4 \mathrm{~d} / \mathrm{wk}, 32 \mathrm{wk}\end{array}$ & Not stated & $\begin{array}{l}\text { Golgi } \\
(2 \mathrm{D})\end{array}$ & $\begin{array}{l}\text { mPFC } \\
\text { oPFC }\end{array}$ & $\begin{array}{l}\text { Decreased spine density } \\
\text { _ }\end{array}$ \\
\hline \multirow[t]{4}{*}{ Singer et al. 2009} & $\begin{array}{c}\text { Rat, SD } \\
\text { adult }\end{array}$ & Mixed & Amphetamine & $\begin{array}{l}\mathrm{IP}(1.0 \mathrm{mg} / \mathrm{kg}) \\
\quad 1 \text { injection } / \mathrm{d}, 1 \mathrm{wk}\end{array}$ & $14-21 \mathrm{~d}$ & $\begin{array}{l}\text { Golgi } \\
(2 \mathrm{D})\end{array}$ & $\mathrm{mPFC}$ & $\begin{array}{l}\text { Increased spine density (apical } \\
\text { dendrites only) }\end{array}$ \\
\hline & & & & & & & oPFC & $\begin{array}{l}\text { Decreased spine density (apical } \\
\text { and basilar dendrites) }\end{array}$ \\
\hline & & & Amphetamine & $\begin{array}{l}\text { Intra-VTA }(2.5 \mu \mathrm{g} / 0.5 \mu \mathrm{L} \\
\text { per side })\end{array}$ & $14-21 \mathrm{~d}$ & $\begin{array}{l}\text { Golgi } \\
(2 \mathrm{D})\end{array}$ & $\mathrm{mPFC}$ & $\begin{array}{l}\text { Decreased spine density (apical } \\
\text { and basilar dendrites) }\end{array}$ \\
\hline & & & & $\begin{array}{l}3 \text { bilaeral injections, } \\
\text { each } 3 \mathrm{~d} \text { apart }\end{array}$ & & & oPFC & $\begin{array}{l}\text { Increased spine density (apical and } \\
\text { basalar dendrites) }\end{array}$ \\
\hline \multicolumn{9}{|l|}{ Nucleus accumbens } \\
\hline Crombag et al. 2005 & $\begin{array}{l}\text { Rat, SD } \\
\text { adult }\end{array}$ & Male & Amphetamine & $\begin{array}{l}\text { SA (0.125 mg/infusion) } \\
2 \mathrm{~h} / \mathrm{d}, 2-3 \mathrm{wk}\end{array}$ & $28 \mathrm{~d}$ & $\begin{array}{l}\text { Golgi } \\
(2 \mathrm{D})\end{array}$ & $\begin{array}{l}\text { Shell } \\
\text { Core }\end{array}$ & Increased spine density \\
\hline Ferrario et al. 2005 & $\begin{array}{l}\text { Rat, Wistar } \\
\text { adult }\end{array}$ & Male & Cocaine & $\begin{array}{l}\mathrm{SA}(0.4 \mathrm{mg} / \mathrm{kg} \text { in } 50 \mu \mathrm{L} / \\
\text { infusion }) \\
1 \mathrm{~h} / \mathrm{d}, 6 \mathrm{~d} / \mathrm{wk}, 3 \mathrm{wk}\end{array}$ & $28 \mathrm{~d}$ & $\begin{array}{l}\text { Golgi } \\
(2 \mathrm{D})\end{array}$ & $\begin{array}{l}\text { Shell } \\
\text { Core }\end{array}$ & $\begin{array}{l}\text { Increased spine density } \\
\text { Increased spine density }\end{array}$ \\
\hline
\end{tabular}




\begin{tabular}{|c|c|c|c|c|c|c|c|c|}
\hline & & & Cocaine & $\begin{array}{l}\mathrm{SA}(0.4 \mathrm{mg} / \mathrm{kg} \text { in } 50 \mu \mathrm{L} / \\
\text { infusion) } \\
6 \mathrm{~h} / \mathrm{d} .6 \mathrm{~d} / \mathrm{wk} .3 \mathrm{wk}\end{array}$ & $28 \mathrm{~d}$ & $\begin{array}{l}\text { Golgi } \\
\text { (2D) }\end{array}$ & $\begin{array}{l}\text { Shell } \\
\text { Core }\end{array}$ & $\begin{array}{l}\text { Increased spine density } \\
\text { Increased spine density (greater } \\
\text { than short access) }\end{array}$ \\
\hline \multirow[t]{4}{*}{ Lee et al. 2006} & $\begin{array}{r}\text { Mouse, SW } \\
\text { adolescent }\end{array}$ & Male & Cocaine & $\begin{array}{l}\text { IP }(30 \mathrm{mg} / \mathrm{kg}) \\
1 \text { injection } / \mathrm{d}, 5 \mathrm{~d} / \mathrm{wk}, \\
4 \mathrm{wk}\end{array}$ & $2 \mathrm{~d}$ & $\begin{array}{l}\text { DiI } \\
(2 \mathrm{D})\end{array}$ & Combined & $\begin{array}{l}\text { Drd1-MSN: increased spine } \\
\text { density (driven by thin and } \\
\text { mushroom) }\end{array}$ \\
\hline & & & & & & & & $\begin{array}{l}\text { Drd2-MSN: increased spine } \\
\text { density (driven by stubby and } \\
\text { mushroom) }\end{array}$ \\
\hline & & & Cocaine & $\begin{array}{l}\text { IP }(30 \mathrm{mg} / \mathrm{kg}) \\
1 \text { injection } / \mathrm{d}, 5 \mathrm{~d} / \mathrm{wk}, \\
4 \mathrm{wk}\end{array}$ & $30 \mathrm{~d}$ & $\begin{array}{l}\text { DiI } \\
(2 \mathrm{D})\end{array}$ & Combined & $\begin{array}{l}\text { Drd1-MSN: increased spine } \\
\text { density (spine morphology not } \\
\text { reported) }\end{array}$ \\
\hline & & & & & & & & Drd2-MSN: no change \\
\hline $\begin{array}{l}\text { Pulipparacharuvil } \\
\text { et al. } 2008\end{array}$ & $\begin{array}{l}\text { Mouse, } \\
\text { C57B6/J } \\
\text { adult }\end{array}$ & Male & Cocaine & $\begin{array}{l}\mathrm{IP}(15 \mathrm{mg} / \mathrm{kg}) \\
1 \text { injection } / \mathrm{d}, 28 \\
\text { consecutive days }\end{array}$ & $1 \mathrm{~d}$ & $\begin{array}{l}\text { GFP } \\
(2 \mathrm{D})\end{array}$ & Combined & Increased spine density \\
\hline \multirow[t]{2}{*}{ Chen et al. 2008} & Rat, SD & Male & Cocaine & $\mathrm{SC}(40 \mathrm{mg} / \mathrm{kg})$ & $8 \mathrm{~d}$ & Golgi & Shell & - \\
\hline & adolescent & & & $\begin{array}{l}1 \text { injection/d, } 7 \\
\text { consecutive days }\end{array}$ & & (2D) & Core & Increased spine density \\
\hline \multirow[t]{4}{*}{ Kim et al. 2009} & $\begin{array}{l}\text { Mouse, SW } \\
\text { adolescent }\end{array}$ & Male & Methylphenidate & $\begin{array}{l}\text { IP }(15 \mathrm{mg} / \mathrm{kg}) \\
1 \text { injection } / \mathrm{d}, 14 \\
\text { consecutive days }\end{array}$ & $2 \mathrm{~d}$ & $\begin{array}{l}\text { DiI } \\
(2 \mathrm{D})\end{array}$ & Combined & $\begin{array}{l}\text { Drd1-MSN: increased spine } \\
\text { density (driven by thin, moreso } \\
\text { in NAc shell) }\end{array}$ \\
\hline & & & & & & & & $\begin{array}{l}\text { Drd2-MSN: increased spine } \\
\text { density in NAc shell only (thin } \\
\text { and stubby) }\end{array}$ \\
\hline & & & Cocaine & $\begin{array}{l}\mathrm{IP}(15 \mathrm{mg} / \mathrm{kg}) \\
\quad 1 \text { injection } / \mathrm{d}, 14\end{array}$ & $2 \mathrm{~d}$ & $\begin{array}{l}\text { DiI } \\
(2 \mathrm{D})\end{array}$ & Combined & $\begin{array}{l}\text { Drd1-MSN: increased spine } \\
\text { density }\end{array}$ \\
\hline & & & & consecutive days & & & & $\begin{array}{l}\text { Drd2-MSN: increased spine } \\
\text { density in NAc shell only (thin } \\
\text { and stubby) }\end{array}$ \\
\hline Singer et al. 2009 & $\begin{array}{l}\text { Rat, SD } \\
\text { adult }\end{array}$ & Mixed & Amphetamine & $\begin{array}{l}\text { IP }(1.0 \mathrm{mg} / \mathrm{kg}) \\
\quad 1 \text { injection } / \mathrm{d}, 1 \mathrm{wk}\end{array}$ & $14-21 \mathrm{~d}$ & $\begin{array}{l}\text { Golgi } \\
\text { (2D) }\end{array}$ & Combined & Increased spine density \\
\hline
\end{tabular}




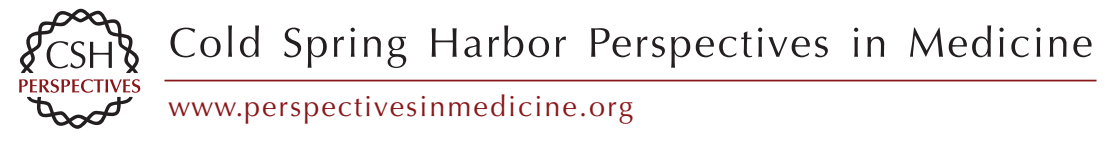

Table 1. Continued

\begin{tabular}{|c|c|c|c|c|c|c|c|c|}
\hline References & Species & Gender & Drug & Route (dose) & Withdrawal & Method & Location & Result \\
\hline & & & Amphetamine & $\begin{array}{l}\text { Intra-VTA }(2.5 \mu \mathrm{g} / 0.5 \mu \mathrm{L} \\
\quad \text { per side })\end{array}$ & $14-21 \mathrm{~d}$ & $\begin{array}{l}\text { Golgi } \\
\text { (2D) }\end{array}$ & Combined & Decreased spine density \\
\hline
\end{tabular}

per side

3 bilateral injections,

Shen et al. 2009 Rat, SD Male Cocaine IP $(30 \mathrm{mg} / \mathrm{kg})$

adult 1 injection $/ \mathrm{d}, 1 \mathrm{wk}$

\section{Russo et al. 2009}

Toda et al. 2010

Maze et at. 2010

Maze et al. 2010

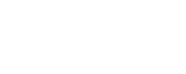

Ren et al. 2010

Mouse, C57B6/J

adult

Kiraly et al. 2010

Mouse,

C57B6/J

adult

LaPlant et al. 2010 Mouse,

C57B6/J

adult
1 injection/d, $1 \mathrm{wk}$

IP $(20 \mathrm{mg} / \mathrm{kg})$

5 over 3 consecutive days

P $(30 \mathrm{mg} / \mathrm{kg}$ )

1 injection/d, 1 wk

IP $(20 \mathrm{mg} / \mathrm{kg}$ )

5 over 3 consecutive days

IP $(30 \mathrm{mg} / \mathrm{kg})$

1 injection/d, 14

consecutive days

IP $(20 \mathrm{mg} / \mathrm{kg})$

1 injection/d, 28

consecutive days

IP $(20 \mathrm{mg} / \mathrm{kg})$

1 injection/d, 4 or 8

consecutive days

IP $(20 \mathrm{mg} / \mathrm{kg})$

5 over 3 consecutive days
No change in spine density, but increase in spines with large heads

Combined Increased spine density

Shell

3D) Core No change

GFP Combined Increased spine density

GFP

(2D)

$1 \mathrm{~d} \quad$ Golgi Shell Increased spine density

(2D) Core -

$30 \mathrm{~min} \quad$ DiI Shell _-

(2D) Core Increased spine density and spine head volume in 8-d group

GFP Combined Increased spine density 


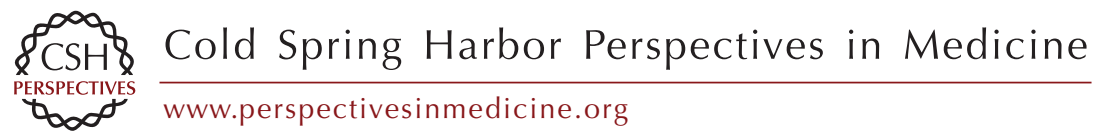

\begin{tabular}{|c|c|c|c|c|c|c|c|c|}
\hline & & & Cocaine & $\begin{array}{l}\text { IP }(20 \mathrm{mg} / \mathrm{kg}) \\
1 \text { injection } / \mathrm{d}, 7 \\
\text { consecutive days }\end{array}$ & $\begin{array}{c}4 \mathrm{~h} \text { and } \\
24 \mathrm{~h}\end{array}$ & $\begin{array}{l}\mathrm{LY} \\
(3 \mathrm{D})\end{array}$ & Shell & $\begin{array}{l}\text { Increased spine density at both } \\
\text { time points (driven by thin } \\
\text { spines) }\end{array}$ \\
\hline & & & & & & & Core & - \\
\hline \multirow[t]{2}{*}{ Deng et al. 2010} & \multirow{2}{*}{$\begin{array}{l}\text { Mouse, } \\
\text { C57B6/J } \\
\text { adult }\end{array}$} & \multirow[t]{2}{*}{ Male } & \multirow[t]{2}{*}{ Amphetamine } & IP $(3 \mathrm{mg} / \mathrm{kg})$ & \multirow[t]{2}{*}{$1 \mathrm{~d}$} & Golgi & Shell & Increased spine density \\
\hline & & & & $\begin{array}{l}1 \text { injection/d, } 21 \\
\text { consecutive days }\end{array}$ & & $(2 \mathrm{D})$ & Core & - \\
\hline \multirow[t]{4}{*}{ Dobi et al. 2011} & \multirow[t]{4}{*}{$\begin{array}{l}\text { Mouse, SW } \\
\text { adult }\end{array}$} & \multirow[t]{4}{*}{ Mixed } & \multirow[t]{2}{*}{ Cocaine } & $\begin{array}{l}\text { IP (30 mg/kg, novel cage) } \\
1 \mathrm{injection/d,5} \mathrm{d/wk,} \\
4 \mathrm{wk}\end{array}$ & \multirow[t]{2}{*}{$2 \mathrm{~d}$} & \multirow[t]{2}{*}{$\begin{array}{l}\text { DiI } \\
(2 \mathrm{D})\end{array}$} & \multirow[t]{2}{*}{ Combined } & $\begin{array}{l}\text { Drd1-MSN: increased spine } \\
\text { density (driven by thin/wide } \\
\text { spines in core) }\end{array}$ \\
\hline & & & & & & & & Drd2-MSN: no change \\
\hline & & & \multirow[t]{2}{*}{ Cocaine } & IP (30 mg/kg, novel cage) & \multirow[t]{2}{*}{$30 \mathrm{~d}$} & \multirow{2}{*}{$\begin{array}{l}\text { DiI } \\
(2 \mathrm{D})\end{array}$} & \multirow[t]{2}{*}{ Combined } & Drd1-MSN: no change \\
\hline & & & & $\begin{array}{l}1 \text { injection/d, } 5 \text { d/wk, } \\
4 \mathrm{wk}\end{array}$ & & & & Drd2-MSN: no change \\
\hline \multirow[t]{2}{*}{ Martin et al. 2011} & \multirow{2}{*}{$\begin{array}{l}\text { Mouse, } \\
\text { C57B6/J } \\
\text { adult }\end{array}$} & \multirow[t]{2}{*}{ Male } & \multirow[t]{2}{*}{ Cocaine } & IP $(30 \mathrm{mg} / \mathrm{kg})$ & \multirow[t]{2}{*}{$3 \mathrm{~d}$} & Golgi & Shell & Increased spine density \\
\hline & & & & $\begin{array}{l}1 \text { injection/d, } 5 \mathrm{~d} / \mathrm{wk} \text {, } \\
4 \mathrm{wk}\end{array}$ & & $(2 \mathrm{D})$ & Core & No change \\
\hline \multirow[t]{3}{*}{ Kim et al. 2011} & \multirow{3}{*}{$\begin{array}{l}\text { Mouse, } \\
\text { C57B6/J } \\
\text { adolescent }\end{array}$} & \multirow[t]{3}{*}{ Male } & \multirow[t]{3}{*}{ Cocaine } & IP $(15 \mathrm{mg} / \mathrm{kg})$ & \multirow[t]{3}{*}{$1 \mathrm{~d}$} & \multirow{3}{*}{$\begin{array}{l}\text { GFP } \\
(2 \mathrm{D})\end{array}$} & Shell & Drd1-MSN: increased spine \\
\hline & & & & 1 injection/d, 5 & & & & density (no effect in Drd2- \\
\hline & & & & Consectutive Mays & & & Core & $\underbrace{\text { MINS) }}$ \\
\hline \multirow[t]{4}{*}{ Wissman et al. 2011} & \multirow{4}{*}{$\begin{array}{c}\text { Rat, SD } \\
\text { adult }\end{array}$} & \multirow{4}{*}{$\begin{array}{l}\text { Male } \\
\text { Female }\end{array}$} & \multirow[t]{4}{*}{ Cocaine } & \multirow{4}{*}{$\begin{array}{l}\text { IP }(15 \mathrm{mg} / \mathrm{kg}) \\
1 \text { injection } / \mathrm{d}, 5 \mathrm{~d} / \mathrm{wk}, \\
5 \mathrm{wk}\end{array}$} & \multirow{4}{*}{$17-21 \mathrm{~d}$} & \multirow{4}{*}{$\begin{array}{l}\text { DiI } \\
(2.5 \mathrm{D})\end{array}$} & Shell & Increased in males, not females \\
\hline & & & & & & & & (females have larger spine \\
\hline & & & & & & & & heads) \\
\hline & & & & & & & Core & $\begin{array}{l}\text { Increased density in male/female, } \\
\text { greater in females (larger heads }\end{array}$ \\
\hline
\end{tabular}

For a review of findings before 2004, please see Robinson and Kolb (2004). Although most psychostimulants have been found to induce robust restructuring, the type of psychostimulant (i.e., cocaine or amphetamine), regimen of administration (i.e., experimenter-administered or selfadministered), route of administration (i.e., intravenous [IV] vs. intraperitoneal [IP]), and the brain region and cell type examined can determine the specific structural changes observed. It is critical that we recognize the vast differences in methodology used across studies, which make it exceedingly difficult to compare results directly. This is further disadvantaged by the diversity of structural modifications seen across, and even within, subregions of brain reward areas. 


\section{BOX 2. MODERN METHODS FOR ANALYSIS OF STRUCTURAL PLASTICITY}

1. Fixed tissue imaging

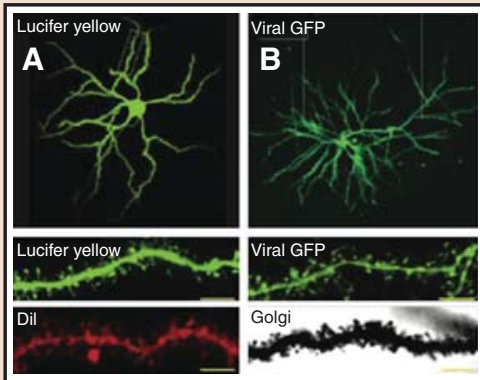

3. In vivo and ex vivo two-photon microscopy

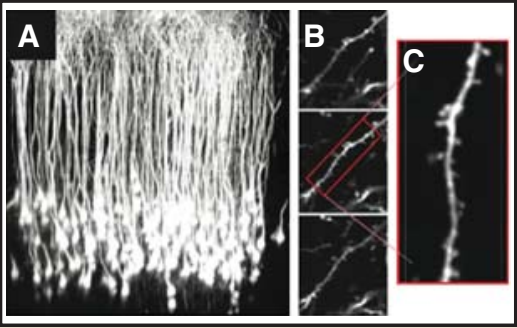

2. Analysis of imaged fixed tissue

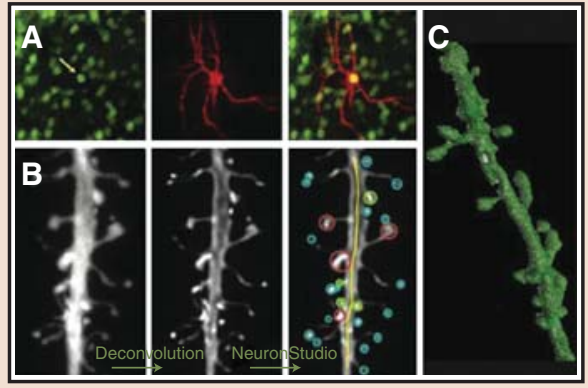

4. Structural and functional plasticity

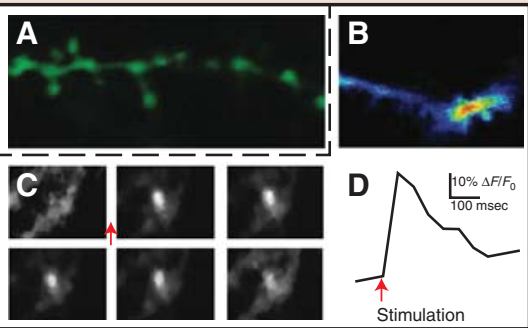

Recent advances in the methods used to visualize and analyze dendritic spines, such as ionophoretic cell loading of fluorescent dyes like Lucifer yellow (LY) (Dumitriu et al. 2011) and diolistic ballistic gene gun delivery of the lipophilic carbocyanide dye Dil (Shen et al. 2008), coupled with 3D rendering of dendritic segments via confocal microscopy, have greatly increased our ability to identify more discrete and subtle changes in dendritic spine morphology. Before these developments, the highest-resolution techniques available were either Golgi-Cox staining or viral-mediated gene transfer of fluorescent proteins (xFP). Although both of these earlier methods are relatively effective and inexpensive, Golgi-Cox staining does not confer the fidelity required to identify stubby spines or determine dendritic spine head volume and neck length reliably, and viral GFP lacks the ability to examine dendritic branching. However, a great strength of viral-mediated gene transfer is the ability to probe and manipulate specific gene targets and their mechanistic roles in structural plasticity. A comparison of NAc MSNs, imaged at $40 \times$, after ( $1 A$ ) cell loading of LY or ( $1 B)$ herpes simplex viral (HSV)-mediated gene transfer of GFP. The close-ups of dendritic segments below, imaged at $100 \times$, show representative levels of detail provided by each technique. Scale bar, $5 \mu \mathrm{m}$. LY and Dil can be used to selectively target and identify cell-type-specific structural plasticity through $(2 A)$ direct injections of $\mathrm{LY}$ or gene gun labeling with Dil in NAc MSNs expressing GFP in either Drd1 or Drd2 neurons. $(2 B)$ The analysts of LY- and Dil-labeled neurons are greatly aided by using semiautomated heuristical software (such as NeuronStudio and Filament/IMARIS), which renders the dendritic segments in 3D and has the ability to classify spine types and volumes without experimenter bias. (2C) An LY loaded dendritic segment from an NAc MSN rendered in 3D in NeuronStudio is shown. The techniques mentioned above, although powerful, are contained to fixed tissue and therefore offer only a brief snapshot into the temporal dynamics of structural plasticity. Two-photon microscopy allows for thick section resolution of spines in live tissue preparations to study the functional relevance of structural plasticity. $(3 A)$ Areas of the cortex, such as the mPFC, are proximal to the brain surface and within range of imaging by two-photon microscopy for longitudinal studies. (3B) A representative two-photon image or a $z$-stack, and $(3 C)$ a dendritic segment from a cortical pyramidal neuron. Although longitudinal imaging in the NAc is extremely difficult, novel technologies such as microendoscopy (Barretto et al. 2011) with high-resolution microlenses (Barretto et al. 2009) may one day make it possible to conduct live imaging of NAc MSN spine plasticity over time. $(4 A, B)$ Ex vivo NAc slice preparations enable direct examination of the functional significance of structural plasticity using calcium indicator dyes and genetically encoded calcium indicators. A combinatorial approach, using real-time observation of structure and function via calcium imaging, will provide a detailed understanding of how stimulants control excitatory transmission. $(4 C, D)$ Glutamate stimulation of an NAc MSN results in rapid calcium signaling within spine and neurites. (Panels 1 and 2 adapted, with permission, from Russo et al. 2010.) 
increases in dendritic spine density are driven predominantly by an increase in thin immature spines (Lee et al. 2006; Kim et al. 2009b; LaPlant et al. 2010; Dobi et al. 2011; Dumitriu 2012). This finding is in line with current electrophysiological data, which suggest that psychostimulants induce a generally more plastic system associated with long-term depression (LTD) at these more immediate time points following cessation of drug administration, or drug challenge. (Thomas et al. 2000, 2008; Thomas and Malenka 2003).

Although much is known regarding structural adaptations in GABAergic NAc MSN projection neurons, we know relatively little regarding structural plasticity of other cell types, such as the cholinergic or GABAergic interneurons. It is clear that the sparsely distributed NAc cholinergic interneurons are activated by cocaine self-administration (Berlanga et al. 2003) and are required for both natural reward learning (Pratt and Kelley 2004; Pratt et al. 2007) and the reinforcing effects of cocaine (Crespo et al. 2006; Witten et al. 2010). However, it is not known how, or even if, drugs of abuse induce restructuring in these neurons. There is an even greater paucity of data on the role that GABAergic interneurons play in psychostimulant-induced synaptic, structural, and behavioral plasticity. Given this, we need a more detailed understanding, not only of the structural changes induced in interneurons by psychostimulants, but also of their functional relevance in driving addiction-like behavior.

\section{OTHER DRUGS OF ABUSE AND NONDRUG STIMULI}

Other drugs of abuse, such as opiates, hallucinogens, and cholinergic agonists like nicotine, have also been found to affect structural plasticity robustly. Nicotine enhances dendritic spine density in the NAc and PFC with some reports suggesting that the magnitude is greater than that of cocaine (Brown and Kolb 2001). Phencyclidine causes similar increases in spine density in the NAc core and mPFC (Flores et al. 2007), whereas 3,4-methylenedioxymethamphetamine (MDMA; ecstasy) increases spine density in the NAc core, shell, and mPFC (Ball et al. 2009). Although a detailed examination of these effects are outside the scope of this article (for review, see Russo et al. 2010; Badiani et al. 2011), it is worth noting that opiates such as heroin and morphine appear to exert entirely opposite structural effects compared with psychostimulants. That is, in the NAc, mPFC, and VTA, chronic opiate administration results in both decreased dendritic arborization complexity and dendritic spine density or reduced soma size (Sklair-Tavron et al. 1996; Robinson and Kolb 1999; Robinson et al. 2002; Russo et al. 2007; Mazei-Robison et al. 2011). However, these opposing structural effects correlate with similar behavioral phenotypes induced by psychostimulant administration, such as acutely enhanced locomotor response, chronic reward sensitization (Russo et al. 2009a; Xia et al. 2011), self-administration, and withdrawal-induced dysphoria (Koob and Le Moal 2005). Moreover, regardless of whether the opiate produces behavioral sensitization or tolerance, the corresponding structural changes are the same. How such a paradoxical effect exists is still a very open debate, and an area of active research.

It is worth noting that several nonpharmacological manipulations, such as stress or environmental enrichment, have the capacity to affect dendritic complexity and dendritic spine density in the mesolimbic reward circuitry (Johansson and Belichenko 2002; Lewis 2004; Christoffel et al. 2011). A number of disease states associated with cognitive dysfunction such as Fragile X, autism spectrum disorder, and schizophrenia show severe deficits in synaptic and structural plasticity (Penzes et al. 2011). Furthermore, stress engages a cross-sensitization mechanism to enhance psychostimulant abuse vulnerability and relapse potential (Marinelli and Piazza 2002; Lu et al. 2003; Covington et al. 2011). It is hypothesized that common mechanisms that increase dendritic spine density in the NAc might be important for these behavioral cross-sensitization mechanisms. A recent study showed that chronic social defeat stress, which induces sensitization, also induces spine formation through an NFkB-dependent mechanism (Christoffel et al. 2011). A similar 
NFкB-dependent mechanism is also necessary for cocaine-induced changes to dendritic spine density (Russo et al. 2009b). Whether these changes act through a shared common mechanism to explain depression and addiction comorbidity, or merely complement each other, still remains to be determined.

\section{SEX DIFFERENCES AND STRUCTURAL PLASTICITY}

Lastly, one often underrepresented characteristic of addiction research is the sexually dimorphic effect of psychostimulants and other drugs of abuse in both humans and animals. Behavioral and pharmacological investigations have found diverse sex differences in psychostimulant addiction liability (Becker and $\mathrm{Hu}$ 2008). For example, female rats acquire cocaine self-administration (Lynch and Carroll 1999) and cocaine-induced place preference (Russo et al. 2003a,b) more rapidly and with lower cocaine doses than male rats. Females are also more likely to relapse after periods of abstinence (Lynch and Carroll 2000). It has been suggested that sexually dimorphic responses are due to sex differences in gonadal hormones, monoaminergic levels, metabolic processes, or D1 receptor sensitivity (Sell et al. 2000; Festa et al. 2004; Nazarian et al. 2004). More recently, a structural and functional basis for these behavioral differences has been identified in the NAc, where cocaine promotes greater induction of dendritic spine density and proportionally more large spines in both the core and shell in female compared with male rats (Forlano and Woolley 2010). Cocaine also promotes a larger increase in miniature excitatory postsynaptic current (EPSC) frequency, a functional correlate of increased spine density along with enhanced behavioral sensitization (Wissman et al. 2011). Although these findings are not unexpected, they do illustrate the necessity to include sex as a variable in experimental design and interpretation of existing data. Considering that existing work has been performed in both male and female subjects (Table 1), often without considering sex as a separate variable, it is worth reexamining what influence this has had on data interpretation.

\section{MECHANISMS OF PSYCHOSTIMULANT- INDUCED NEUROADAPTATION}

It is commonly suggested that addiction is a disease marked by extreme forms of pathological learning (Hyman et al. 2006). Learning phenomena are postulated to correlate with forms of synaptic plasticity, most notably, long-term potentiation (LTP) and LTD. Interestingly, LTP and LTD are established regulators of cell morphology (for review, see Carlisle and Kennedy 2005; Bourne and Harris 2007). That is, in general, LTD induction results in shrinkage and retraction of dendritic spines and their presynaptic contacts (Nagerl et al. 2004; Becker et al. 2008), whereas LTP induction results in new spine formation or enlargement of preexisting spines (Matsuzaki et al. 2004; Nagerl et al. 2004). Therefore, it is believed that the synaptic strengthening of an immature thin spine into a more stable and functional mushroom spine involves an activity-dependent mechanism that recruits intracellular structural and molecular machinery (Holtmaat and Svoboda 2009). Mechanistically, LTP and LTD are believed to initiate this dendritic spine restructuring through the activation of signaling pathways that recruit numerous cytoskeletal-associated proteins, altering their synthesis and location along dendritic segments (Tada and Sheng 2006). The end point of this recruitment is the polymerization of preexisting actin cytoarchitecture and the consequent internalization or insertion of $\alpha$-amino-3-hydroxl-5-methyl-4-isoxazole-propionate (AMPA) glutamate receptors into the postsynaptic density (PSD) (see Box 2 for description) (Harris et al. 1992). Spinogenesis and stabilization of thin spines into mushroom spines is associated with an enlarged PSD and increased AMPA receptor surface expression that lasts for months (Holtmaat et al. 2005; Zuo et al. 2005), presenting a molecular substrate underlying long-term behavioral maladaptations such as those seen in addiction. Thus, leading theories on drug addiction suggest that drugs of abuse hijack molecular and cellular processes, such as these, leading to persistent maladaptive behavioral responses in addiction (Hyman and Malenka 2001; Hyman et al. 2006). 
The temporal regulation of synaptic and structural plasticity suggests that dendritic spine morphology exists along an ever-changing continuum (Fig. 2). Acutely following cocaine administration there is an increase in thin spines (Shen et al. 2009) that is paralleled by induction of LTD and behavioral sensitization (Thomas et al. 2001), which might reflect the development of silent synapses (Kerchner and Nicoll 2008). Although the majority of glutamatergic synapses contain both AMPA and N-methyl-D-aspartate (NMDA) receptors, silent synapses appear to functionally contain only NMDA receptors and typically do not operate in response to AMPA-mediated activity (Liao et al. 1995). Indeed, exposure to cocaine robustly generates immediate and relatively short-lived silent synapses in the NAc by membrane insertion of NR2Bcontaining NMDARs (Huang et al. 2009), in a cAMP-element binding protein (CREB)-dependent manner (Brown et al. 2011). Interestingly, silent synapses do not contribute significantly to the overall tone of an EPSC, because AMPA-mediated, rather than NMDAR-mediated, currents

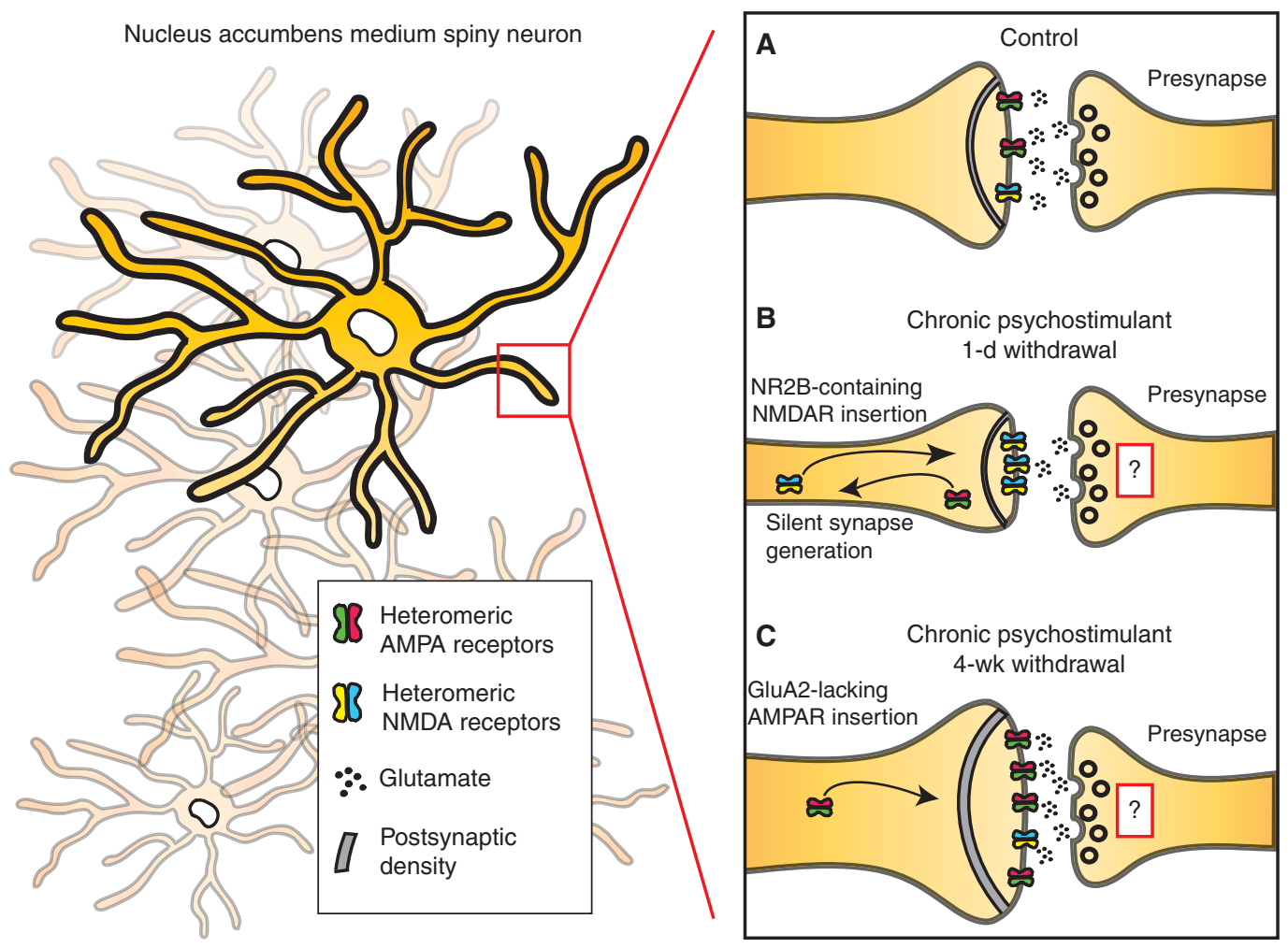

Figure 2. Schematic of psychostimulant-induced synaptic and structural plasticity. $(A)$ Repeated administration of psychostimulants results in rapid, although transient, shifts in $\alpha$-amino-3-hydroxl-5-methyl-4-isoxazolepropionate (AMPA) glutamate receptor and $N$-methyl-D-aspartate (NMDA) receptor surface membrane expression in the postsynaptic density (PSD) of nucleus accumbens (NAc) medium spiny neurons (MSNs). These shifts in receptor composition are coupled to alterations in dendritic spine structural plasticity, which correlate with types of synaptic plasticity. $(B)$ Specifically, acute withdrawal from chronic cocaine induces the formation of thin spines and silent synapses via insertion of NR2B-containing NMDARs, as well as results in long-term depression (LTD). ( $C$ ) As the withdrawal period extends, GluA2-lacking AMPARs are inserted into the spine head, and there is a shift toward mushroom spines with increased spine head diameter and enhanced long-term potentiation (LTP). Acute reexposure to cocaine following extended withdrawal periods (not depicted above) results in a rapid induction of thin spines and LTD, similar to what is observed in panel $B$. The role of presynaptic structural plasticity is currently unknown. 
provide the majority of EPSC strength. NMDAR contribution is limited to coincidence detection of the activation state of an excitory synapse, making them important substrates for LTP induction. This has led to the hypothesis that silent synapses act as modulators of metaplasticity, providing a mechanism by which synapses can be rapidly primed for subsequent changes in plasticity such as LTP and LTD (Abraham and Bear 1996; Malenka and Bear 2004; Marie et al. 2005). Induction of silent synapses immediately following cocaine administration places the NAc in a primed state and vulnerable to enhanced LTP during withdrawal (Lee and Dong 2011).

This concept is corroborated by findings that during cocaine withdrawal, there is an increase in larger and more stable mushroom spines accompanied by the disappearance or retraction of thin spines (Shen et al. 2009). However, in the sensitization model, the majority of inserted AMPA receptors are GluA2-containing. The switch toward GluA2-lacking AMPA receptors has been reported under extended access cocaine self-administration models, and at longer time points. GluA2-lacking AMPA receptors, which show increased $\mathrm{Ca}^{2+}$ conductance and are associated with increased synaptic strength, may play a role in the long-lasting potentiation of glutamatergic synapses reported in self-administration models (Boudreau and Wolf 2005; Boudreau et al. 2007; Wolf and Tseng 2012). It is noteworthy that insertion and accumulation of GluA2lacking AMPARs in the NAc are partly dependent on volitional control of psychostimulant administration (McCutcheon et al. 2011). It has been proposed that accumulation of NAc GluA2-lacking AMPARs mediates the behavioral expression of incubation of cocaine craving, potentially acting as a mechanism for the enhanced drug craving and relapse rates observed clinically (Conrad et al. 2008; Pickens et al. 2011). As well, reexposure to acute cocaine following 2 or 4 wk of withdrawal results in a rapid reduction in spine head diameter (Shen et al. 2009), decreased surface expressed AMPA receptors (Boudreau et al. 2007), and synaptic strength depression (Kourrich et al. 2007). It will be interesting to know whether incubation following self-administration affects dendritic spine structural plasticity mirroring these molecular and physiological changes (for references, see previous section and Table 1).

Although much of our discussion has focused on postsynaptic plasticity, psychostimulants also reduce cystine-glutamate exchange and subsequently decrease the bioavailability of extra-synaptic glutamate in the NAc (Baker et al. 2003), possibly through a presynaptic mechanism. The reduction of available extrasynaptic glutamate results in decreased group II metabotropic glutamate receptor (mGlurR) activation, which under normal circumstances acts to negatively regulate glutamate release ( $\mathrm{Ba}$ ker et al. 2002; Xi et al. 2002), and in the presence of cocaine challenge, allows for the normalization of NAc glutamate tone (Pierce et al. 1996). This imbalance in glutamatergic tone between synaptic and nonsynaptic pools following drug administration has been termed the glutamate homeostasis hypothesis of addiction, and is believed to underlie, in part, how drugs of abuse modulate neuroplasticity in the NAc (Kalivas 2009). In conjunction with the synaptic plasticity mechanisms already mentioned, a delicate regulatory network appears to guide how NAc MSNs transition from their normal to the addicted state, taking into account extracellular nonsynaptic glutamate levels and changes in MSN intrinsic membrane excitability (Wolf 2011). Our understanding of the structural presynaptic component is still far too limited and should be a focus of future work.

\section{MOLECULAR MECHANISMS OF PSYCHOSTIMULANT-INDUCED STRUCTURAL PLASTICITY}

A question in the field has been how drugs of abuse are capable of exerting long-lasting behavioral control following their initial, relatively transient, effects. The transient nature of gene expression changes following acute drug administration, especially when compared clinically with a lifetime of addiction, requires a mechanism that allows for sustainable or sensitized transcription events. Transcriptional regulators such as transcription factors, histone modifications, and noncoding microRNAs have been 
found to potently regulate addictive behavior and synaptic plasticity in response to psychostimulants (Maze and Russo 2010). Such transcriptional mechanisms allow not only for steady-state regulation of mRNA expression, but also may act as inducibility factors during subsequent environmental stimulation (Robison and Nestler 2011). This molecular memory provides a conceptual framework for how previous life experiences, like adolescent or prenatal stress, can prime a system and influence subsequent drug vulnerabilities. A considerable body of work in animal models supports such mechanisms following repeated psychostimulant administration (Fig. 3). Several transcription factors have been implicated in addiction, including $\triangle \mathrm{FosB}, \mathrm{CREB}, \mathrm{MEF} 2$, and NFкB (for review, see Maze and Russo 2010; Robison and Nestler 2011). Although these represent just a narrow subset of known transcription factors in the brain, they are robustly implicated in various aspects of behavioral and physiological plasticity in response to psychostimulants. Here we explore their direct roles in structural plasticity (Fig. 3).

\section{$\Delta$ FosB and Other FOS Family Proteins}

$\Delta$ FosB, a member of the FOS family of immediate early genes, represents one of the most well-understood transcription factors mediating addiction (McClung et al. 2004). Although all FOS family members are transiently expressed following acute drug administration, $\Delta$ FosB displays the unique trait of extended and accumulated expression during repeated administration (Hope et al. 1992). This vastly improved stability is conferred by alternative splicing of full-length FosB into its truncated $\Delta$ FosB isoform, severing two degron domains required for proteosomal degradation and clearance (Carle et al. 2007). This stability is further enhanced by phosphorylation at serine 27 , resulting in a molecular switch that presents one of the few truly persistent molecular changes following drug exposure, lasting weeks into withdrawal (UleryReynolds et al. 2009). This selective $\Delta$ FosB induction is seen most robustly in the NAc, but also observed in other reward areas such as the
PFC. Interestingly, in the NAc and dorsal striatum, both self-administered and experimenteradministered psychostimulants induce $\Delta$ FosB to increase drug reward (Kelz et al. 1999; Colby et al. 2003) via a Drd1-MSN selective mechanism (Robison and Nestler 2011). This finding is consistent with a recent report showing morphological alterations occurring most robustly and with the greatest persistence in Drd1-MSN populations.

Although protein stability and accumulation of $\Delta$ FosB are known to play a role in this process, recent evidence also points to epigenetic control of $\Delta$ FosB through a G9a-dependent mechanism (Maze et al. 2010). G9a and G9alike protein (GLP) are lysine methyltransferases (KMTs) that methylate and repress gene expression. Following repeated cocaine administration, there is a reduction in G9a and GLP, resulting in enhanced $\Delta$ FosB transcription. The subsequent accumulation of $\Delta$ FosB in the NAc leads to the disinhibition and enhancement of dendritic spine density on NAc MSNs, possibly through transcription of RhoGTPase and cytoskeleton-associated genes. Structurally, $\Delta$ FosB is both sufficient and necessary for cocaine-induced increases in dendritic spine density (Maze et al. 2010). Through the use of large-scale microarray studies, we do, indeed, know that along with roughly $25 \%$ of all genes regulated by cocaine in the NAc, $\Delta$ FosB selectively modulates several cytoskeleton-associated genes implicated in structural plasticity, such as cofilin, actinrelated protein 4 (ARP4), and activity-regulated cytoskeletal protein (Arc) (McClung and Nestler 2003; Renthal et al. 2009). Small RhoGTPases (discussed in detail below) upstream of ARP and cofilin, which are required for actin cycling, polymerization, and nucleation, are likewise down-regulated by cocaine (Kim et al. 2009a). This positions $\Delta$ FosB as a key director of psychostimulant-induced plasticity.

\section{Cyclic AMP Response Element Binding Protein (CREB)}

CREB is another transcription factor activated in the NAc by drugs of abuse. Interestingly, as opposed to $\triangle \mathrm{FosB}, \mathrm{CREB}$ activity is induced in 
S.A. Golden and S.J. Russo

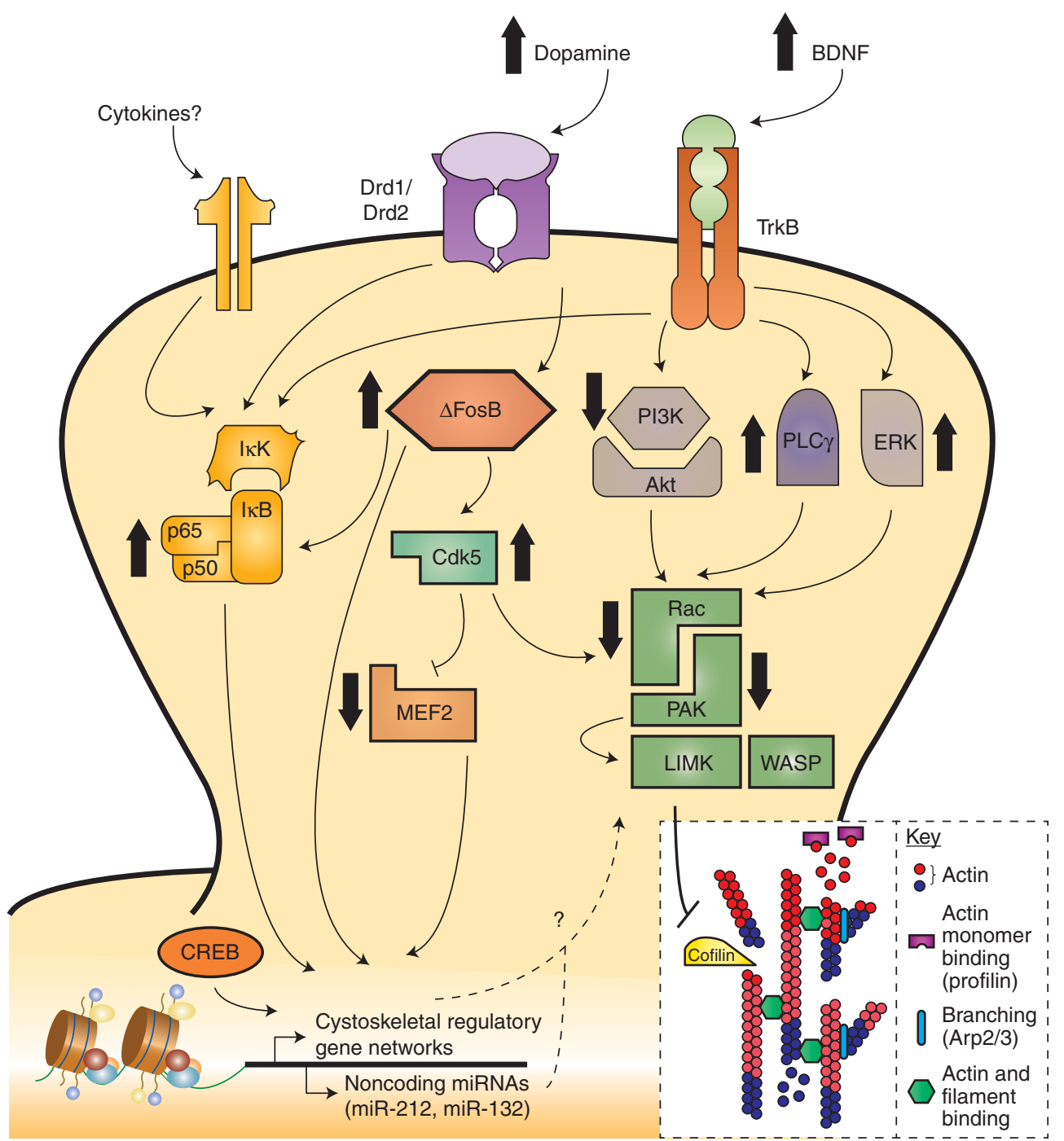

Figure 3. Molecular mechanisms and signaling pathways implicated in psychostimulant-induced structural plasticity. Several transcription factors, including, but not limited to, NFкB, $\Delta$ FosB, myocyte enhancing factor 2 (MEF2), and cyclic AMP response element binding protein (CREB), regulate dendritic spine structural and synaptic plasticity. In addition to dopamine and opioid neurotransmission, brain-derived neurotrophic factor (BDNF) and other neurotrophic signals regulate this transcriptional machinery via receptor tyrosine kinasemodulated activation of phosphoinositide 3-kinase (PI3K), thymoma viral proto-oncogene (Akt), Ras-extracellular regulated kinase (ERK), and NFKB pathways. The common downstream effectors of these signaling cascades are believed to be, in large part, members of the small RhoGTPase family such as Ras-related C3 botulinum toxin substrate 1 (Rac1), which then alter actin cytoskeletal dynamics through downstream targeting of PAK, LIMK, and ultimately cofilin. It is further speculated that NFKB activation may occur through a cytokine receptor-dependent mechanism to control spine plasticity; however, this is yet to be proven empirically. Psychostimulant-induced changes in structural plasticity therefore have many potential signaling mechanisms through which to alter behavioral and molecular effects, often culminating in modulation of actin assembly and cycling via altered gene expression. PLC $\gamma$, phospholipase $\mathrm{C} \gamma$; I $\kappa \mathrm{K}$, inhibitor of $\kappa \mathrm{B}$ kinase; I $\mathrm{B}$, inhibitor of $\kappa \mathrm{B}$; TrkB, tyrosine receptor kinase B; Drd, dopamine receptor; LIMK, lim domain kinase; WASP, Wiskott-Aldrich Syndrome proteins; Cdk5, cyclin-dependent kinase-5. 
both Drd1-MSN and Drd2-MSN populations in response to psychostimulants, ultimately leading to decreased reward sensitivity (Carlezon et al. 1998, 2005). It is now understood that cocaine-induced generation of NAc silent synapses occurs through a CREB-dependant transcriptional mechanisms that ultimately increases synaptic incorporation of NR2B-containing NMDARs (Brown et al. 2011). This recent finding corroborates earlier experiments implicating CREB activity as a positive regulator of MSN excitability (Dong et al. 2006). Although we do not understand precisely how CREB may be modulating structural plasticity in the NAc, there is evidence suggesting that CREB can induce spinogenesis in other brain areas (Murphy and Segal 1997), possibly through transcriptional targets such as myocyte enhancing factor 2C (MEF2C) and brain-derived neurotrophic factor (BDNF). More directly, there is recent evidence implicating the CREB-induced activation of miR-132 as critical to spinogenesis via p250GAP (Wayman et al. 2008), a GTPase activating protein (GAP), which inactivates the small RhoGTPase Racl through catalysis of conversion of GTP to GDP (Impey et al. 2010). Similarly, cocaine regulates other noncoding microRNAs such as miR-212, which acts to amplify cocaine-induced CREB signaling and results in a blunted behavioral response (Hollander et al. 2010), possibly through a BDNF-dependent mechanism (Im et al. 2010).

\section{Nuclear Factor- $\kappa \mathrm{B}(\mathrm{NF} \kappa \mathrm{B})$}

$\mathrm{NF \kappa B}$ is a dimeric transcription factor composed of five possible subunits, most notably p65 and p50. When inactive, NFкB is sequestered in the cytoplasm by inhibitor of $\kappa \mathrm{B}$ (I $\mathrm{KB}$ ) until phosphorylated by its upstream effecter inhibitor of $\kappa B$ kinase (ІКK) (Hacker and Karin 2006). Once phosphorylated, IкB is polyubiquitylated and degraded by proteosomes, freeing NFKB subunits for translocation from the cytoplasm into the nucleus, where they can regulate transcriptional targets. p65containing NFKB complexes are selectively localized to synapses and upon activity-depen- dent activation transported to the nucleus (Meffert et al. 2003). Although initially identified as a transcription factor critical to immune response (Cai 2009), a rapidly growing literature is directly implicating central nervous system NFкB signaling in dendritic morphogenesis (Boersma et al. 2011; Gutierrez and Davies 2011). Along these lines, repeated cocaine administration up-regulates $\mathrm{NF \kappa} B$ signaling in the $\mathrm{NAc}$ in a $\triangle \mathrm{FosB}$-dependent manner, and this activity is required for cocaine-induced dendritic spine formation (Russo et al. 2009b). Unfortunately, we currently do not know what structural plasticity target genes are regulated by psychostimulant-induced NFкB regulation, although this is an active area of research. Early results suggest that both p65 and p50 subunits bind to the Racl promoter, directly linking NFкB to cytoskeletal remodelers (SA Golden and SJ Russo, unpubl.). Future experiments will seek to extend these findings to determine whether psychostimulants control Racl expression through an NFKB mechanism. Myocyte Enhancing Factor 2 (MEF2) and
Cyclin-Dependent Kinase 5 (Cdk5)

Although we have highlighted a few findings above suggesting that cocaine-induced enhancement of dendritic spine density controls aspects of behavioral sensitization, a few recent reports suggest that this simplified view is not the entire story (Norrholm et al. 2003; Pulipparacharuvil et al. 2008). In the NAc, cyclin-dependent kinase 5 (Cdk5) is induced through a $\Delta$ FosB-dependent mechanism following repeated cocaine (Bibb et al. 2001; Kumar et al. 2005). Cdk5 is known to modulate the activity of small RhoGTPases (Cheung and Ip 2007), and inhibition of Cdk5 disrupts cocaine-induced dendritic spine proliferation (Bibb et al. 2001; Norrholm et al. 2003). Interestingly, cocaine-in-duced activation of $\mathrm{Cdk} 5$, via phosphorylation, leads to direct inhibition of MEF2 and proliferation of dendritic spines. MEF2 inhibition by Cdk5 may allow for the transcription of actin cytoskeleton-associated target genes such as Wiskott-Aldrich Syndrome proteins (WASPs) and WASP-family verprolin homologs (WAVEs), 
which contain MEF2 binding sites within the proximal promoter regions. Similarly, Cdk5 can also directly regulate WAVE1 activity to promote spinogenesis (Kim et al. 2006). This provides a somewhat parallel mechanism by which both Cdk5 and MEF2 can ultimately regulate dendritic morphology.

Unexpectedly, both inhibition of Cdk5 and activation of MEF2 enhance behavioral responses to cocaine administration, even though they block cocaine-induced NAc dendritic spine formation (Bibb et al. 2001; Benavides et al. 2007; Taylor et al. 2007; Meyer et al. 2008; Pulipparacharuvil et al. 2008). This paradox suggests that the central dogma whereby NAc dendritic spine density translates to behavioral sensitization is not completely correct. Several hypotheses attempt to account for these differences. Perhaps alterations in dendritic spine density act as a homeostatic adaptation to compensate for other physiological changes following repeated cocaine use, such as extra-synaptic glutamatergic tone and reduction in glutamatergic stimulation of MSNs by cortical prefrontal afferents. Conversely, perhaps the net effect of repeated psychostimulant administration is the induction of NAc dendritic spine proliferation, via $\triangle$ FosB, of multiple downstream targets (i.e., NFkB, Cdk5, and MEF2, among others), and the net behavioral consequence is sensitized behavior. However, individual pathways such as MEF2 and Cdk5, when examined in isolation from the complete signaling cascade, elicit behavioral effects through their own diverse, and not well understood, downstream molecular pathways. Finally, it is still not clear whether the effects of MEF2 and CDK5 act within Drd1 or Drd 2 cells to control spinogenesis and sensitization. This highlights the need to better understand, on a cell-type-specific basis, the roles and transcriptional targets of individual downstream effectors controlling synaptic and structural plasticity.

\section{Intracellular RhoGTPase Regulation}

Small RhoGTPases are a subfamily of the Ras superfamily of small guanosine triphosphates
(GTPases) and are key regulators of extracellular-stimulus-mediated signal transduction to the actin cytoskeleton, where they directly influence actin polymerization and subsequent structural plasticity (Etienne-Manneville and Hall 2002). In the mammalian central nervous system, their role has further been refined to neuronal development, growth cone dynamics, neuronal migration, and dendritic spine morphogenesis (Linseman and Loucks 2008; Dietz et al. 2012). With respect to their role in synaptic and structural plasticity, the RhoGTPases Rac1, Cdc42, and RhoA have been most heavily studied. In the broadest sense, $\mathrm{Racl} / \mathrm{Cdc} 42$ promote spine formation and growth, whereas RhoA tends to inhibit spine morphogenesis (Luo 2000; Negishi and Katoh 2005). In their basal state, RhoGTPases are GDP-bound and inactive, transitioning to their activate conformation by guanine nucleotide exchange factors (GEFs) that catalyze the exchange of GDP for GTP. Once GTP-bound, RhoGTPases form signaling complexes with downstream targets, leading to regulation of $\mathrm{ADF} /$ cofilin, the substrate that actively polymerizes actin monomers and provides the mechanical component needed for synaptic restructuring (Sarmiere and Bamburg 2004). GTPase-activating proteins (GAPs) return RhoGTPases to their inactive states by accelerating hydrolysis of GTP to GDP. This complex regulatory network of GEFs, GAPs, and GTPases allows for extremely precise temporal and spatial control of actin dynamics (Tolias et al. 2011)

Recently, it has become apparent that drugs of abuse directly regulate RhoGTPase signaling proteins, as well as their upstream GEFs and GAPs, to effect synaptic and structural plasticity. Kalirin7 expression, a GEF localized to the PSD that regulates Rac1 activation (Xie et al. 2007), is robustly enhanced in the NAc by cocaine administration. Interestingly, cocaine administration favors expression of Kalirin7 and a splice variant, $\Delta$-Kalirin7 (Mains et al. 2011), that can distinctively regulate dendritic spine density (Ma et al. 2008) and spine head diameter (Schiller et al. 2008). In line with these findings, $\mathrm{ka}$ lirin 7 knockout mice show reduced conditioned place preference for cocaine and fail to show 
cocaine-induced increases in dendritic spine density (Kiraly et al. 2010). The brain region specificity and regulatory ability of kalirin 7 splicing transcripts could reflect a novel molecular switch for cocaine to regulate distinct structural plasticity events across brain regions.

Another GEF, Ras-GRF1, is also up-regulated in response to cocaine and known to regulate addiction-like behavior (Zhang et al. 2007). Constitutive overexpression of wholebrain Ras-GRF1 enhances drug sensitization and reward, whereas mice lacking Ras-GRF1 show attenuated sensitivity. Furthermore, RasGRF1 is known to modulate $\Delta$ FosB expression, which, in turn, can promote dendritic spine formation (Maze et al. 2010). Although a great deal less is known regarding the role of GAPs in addiction, one study has identified mutations in RhoGAP18B in Drosophila as critical to altering drug-related behavioral sensitivity (Rothenfluh et al. 2006). These early studies highlight the potential importance of RhoGTPase family members, and their associated upstream and downstream targets, in modulation of synaptic and structural plasticity following exposure to drugs of abuse.

\section{CLOSING REMARKS}

As we have highlighted throughout this article, psychostimulant-induced neural plasticity reflects one of the most enduring changes in the brain associated with addiction and may explain the persistent nature of the disease. Although much progress has been made in understanding its role, there is far more work to be done. For example, although we have focused primarily on structural plasticity in NAc and PFC, it is critical to keep in mind that these circuits do not work in isolation. A whole-brain systems understanding of psychostimulant-induced plasticity must be applied to understand how the cellular and molecular mechanisms within each cell type control pathological behaviors relevant to addiction. There is an overwhelming complexity of molecular mechanisms controlling very distinct aspects of structural plasticity. Through recent advances in "next-generation" sequencing and cell-type-specific transcriptional profiling, we can gain a far more detailed understanding of the gene regulatory mechanisms controlled by addictive drugs. As well, with new transgenic techniques to label cell types combined with high-resolution spine morphology assays, we can greatly expand our knowledge of structural plasticity beyond PFC glutamatergic pyramidal neurons and NAc GABAergic spiny neurons, which represent only a small fraction of the neuronal cell types that undergo stimulant-induced structural plasticity. Finally, although a few recent studies have identified the functional correlates of structural plasticity, we need far more causal information to understand their role in addictive behavior. By using viral gene transfer and optogenetic techniques, we can define the functional role of such plasticity within each neuronal cell type on a circuit level. At such a level, these investigations are needed for a concrete mechanistic understanding of plasticity in addiction.

\section{ACKNOWLEDGMENTS}

We thank Daniel Christoffel, Mitra Heshmati, and Madeline Pfau for their helpful discussions of the manuscript. We also thank Daniel Christoffel, Keithara Davis, Sarah Crowe, and Graham Ellis-Davies for providing the images used in Box 2. Finally, we thank Quincy LaPlant for his help in organizing Table 1. Preparation of this manuscript is supported by a grant from the National Institute of Mental Health: R01 MH090264 (to S.J.R.).

\section{REFERENCES}

Abraham WC, Bear MF. 1996. Metaplasticity: The plasticity of synaptic plasticity. Trends Neurosci 19: 126-130.

Badiani A, Oates MM, Day HE, Watson SJ, Akil H, Robinson TE. 1999. Environmental modulation of amphetamineinduced c-fos expression in D1 versus D2 striatal neurons. Behav Brain Res 103: 203-209.

Badiani A, Belin D, Epstein D, Calu D, Shaham Y. 2011. Opiate versus psychostimulant addiction: The differences do matter. Nat Rev Neurosci 12: 685-700.

Baker DA, Xi ZX, Shen H, Swanson CJ, Kalivas PW. 2002. The origin and neuronal function of in vivo nonsynaptic glutamate. J Neurosci 22: 9134-9141.

Baker DA, McFarland K, Lake RW, Shen H, Tang XC, Toda S, Kalivas PW. 2003. Neuroadaptations in cystine- 
S.A. Golden and S.J. Russo

glutamate exchange underlie cocaine relapse. Nat Neurosci 6: $743-749$.

Ball KT, Wellman CL, Fortenberry E, Rebec GV. 2009. Sensitizing regimens of $( \pm) 3,4$-methylenedioxymethamphetamine (ecstasy) elicit enduring and differential structural alterations in the brain motive circuit of the rat. Neuroscience 160: 264-274.

Barretto RP, Messerschmidt B, Schnitzer MJ. 2009. In vivo fluorescence imaging with high-resolution microlenses. Nat Methods 6: 511-512.

Barretto RP, Ko TH, Jung JC, Wang TJ, Capps G, Waters AC, Ziv Y, Attardo A, Recht L, Schnitzer MJ. 2011. Time-lapse imaging of disease progression in deep brain areas using fluorescence microendoscopy. Nat Med 17: 223-228.

Becker JB, Hu M. 2008. Sex differences in drug abuse. Front Neuroendocrinol 29: 36-47.

Becker N, Wierenga CJ, Fonseca R, Bonhoeffer T, Nagerl UV. 2008. LTD induction causes morphological changes of presynaptic boutons and reduces their contacts with spines. Neuron 60: 590-597.

Benavides DR, Quinn JJ, Zhong P, Hawasli AH, DiLeone RJ, Kansy JW, Olausson P, Yan Z, Taylor JR, Bibb JA. 2007. Cdk5 modulates cocaine reward, motivation, and striatal neuron excitability. J Neurosci 27: 12967-12976.

Berlanga ML, Olsen CM, Chen V, Ikegami A, Herring BE, Duvauchelle CL, Alcantara AA. 2003. Cholinergic interneurons of the nucleus accumbens and dorsal striatum are activated by the self-administration of cocaine. $\mathrm{Neu}$ roscience 1204: 1149-1156.

Bertran-Gonzalez J, Bosch C, Maroteaux M, Matamales M, Herve D, Valjent E, Girault JA. 2008. Opposing patterns of signaling activation in dopamine D1 and D2 receptorexpressing striatal neurons in response to cocaine and haloperidol. J Neurosci 28: 5671-5685.

Bibb JA, Chen J, Taylor JR, Svenningsson P, Nishi A, Snyder GL, Yan Z, Sagawa ZK, Ouimet CC, Nairn AC, et al. 2001. Effects of chronic exposure to cocaine are regulated by the neuronal protein Cdk5. Nature 410: 376-380.

Boersma MC, Dresselhaus EC, De Biase LM, Mihalas AB, Bergles DE, Meffert MK. 2011. A requirement for nuclear factor- $\mathrm{\kappa} \mathrm{B}$ in developmental and plasticity-associated synaptogenesis. J Neurosci 31: 5414-5425.

Boudreau AC, Wolf ME. 2005. Behavioral sensitization to cocaine is associated with increased AMPA receptor surface expression in the nucleus accumbens. J Neurosci 25: 9144-9151.

Boudreau AC, Reimers JM, Milovanovic M, Wolf ME. 2007. Cell surface AMPA receptors in the rat nucleus accumbens increase during cocaine withdrawal but internalize after cocaine challenge in association with altered activation of mitogen-activated protein kinases. J Neurosci 27: 10621-10635.

Bourne J, Harris KM. 2007. Do thin spines learn to be mushroom spines that remember? Curr Opin Neurobiol 17: $381-386$.

Brog JS, Salyapongse A, Deutch AY, Zahm DS. 1993. The patterns of afferent innervation of the core and shell in the "accumbens" part of the rat ventral striatum: Immunohistochemical detection of retrogradely transported fluoro-gold. J Comp Neurol 338: 255-278.
Brown RW, Kolb B. 2001. Nicotine sensitization increases dendritic length and spine density in the nucleus accumbens and cingulate cortex. Brain Res 899: 94-100.

Brown TE, Lee BR, Mu P, Ferguson D, Dietz D, Ohnishi YN, Lin Y, Suska A, Ishikawa M, Huang YH, et al. 2011. A silent synapse-based mechanism for cocaine-induced locomotor sensitization. J Neurosci 31: 8163-8174.

Cai D. 2009. NFкB-mediated metabolic inflammation in peripheral tissues versus central nervous system. Cell Cycle 8: $2542-2548$.

Carle TL, Ohnishi YN, Ohnishi YH, Alibhai IN, Wilkinson MB, Kumar A, Nestler EJ. 2007. Proteasome-dependent and -independent mechanisms for FosB destabilization: Identification of FosB degron domains and implications for DeltaFosB stability. Eur J Neurosci 25: 3009-3019.

Carlezon WA Jr, Thome J, Olson VG, Lane-Ladd SB, Brodkin ES, Hiroi N, Duman RS, Neve RL, Nestler EJ. 1998. Regulation of cocaine reward by CREB. Science 282: 2272-2275.

Carlezon WA Jr, Duman RS, Nestler EJ. 2005. The many faces of CREB. Trends Neurosci 28: 436-445.

Carlisle HJ, Kennedy MB. 2005. Spine architecture and synaptic plasticity. Trends Neurosci 28: 182-187.

Chen BT, Hopf FW, Bonci A. 2010. Synaptic plasticity in the mesolimbic system: Therapeutic implications for substance abuse. Ann NY Acad Sci 1187: 129-139.

Cheung ZH, Ip NY. 2007. The roles of cyclin-dependent kinase 5 in dendrite and synapse development. Biotechnol J 2: 949-957.

Christoffel DJ, Golden SA, Dumitriu D, Robison AJ, Janssen WG, Ahn HF, Krishnan V, Reyes CM, Han MH, Ables JL, et al. 2011. ІкB kinase regulates social defeat stress-induced synaptic and behavioral plasticity. J Neurosci 31: 314-321.

Colby CR, Whisler K, Steffen C, Nestler EJ, Self DW. 2003. Striatal cell type-specific overexpression of $\Delta \mathrm{FosB}$ enhances incentive for cocaine. J Neurosci 23: 2488-2493.

Conrad KL, Tseng KY, Uejima JL, Reimers JM, Heng LJ, Shaham Y, Marinelli M, Wolf ME. 2008. Formation of accumbens GluR2-lacking AMPA receptors mediates incubation of cocaine craving. Nature 454: 118-121.

Coutinho A, Flynn C, Burdo TH, Mervis RF, Fox HS. 2008. Chronic methamphetamine induces structural changes in frontal cortex neurons and upregulates type I interferons. J Neuroimmune Pharmacol 3: 241-245.

Covington HE III, Maze I, Sun H, Bomze HM, DeMaio KD, Wu EY, Dietz DM, Lobo MK, Ghose S, Mouzon E, et al. 2011. A role for repressive histone methylation in cocaine-induced vulnerability to stress. Neuron 71: 656670.

Crespo JA, Sturm K, Saria A, Zernig G. 2006. Activation of muscarinic and nicotinic acetylcholine receptors in the nucleus accumbens core is necessary for the acquisition of drug reinforcement. J Neurosci 26: 6004-6010.

Crombag HS, Gorny G, Li Y, Kolb B, Robinson TE. 2005. Opposite effects of amphetamine self-administration experience on dendritic spines in the medial and orbital prefrontal cortex. Cereb Cortex 15: 341-348.

Dalley JW, Cardinal RN, Robbins TW. 2004. Prefrontal executive and cognitive functions in rodents: Neural and 
neurochemical substrates. Neurosci Biobehav Rev 28: 771-784.

Dietz DM, Sun H, Lobo MK, Cahill ME, Chadwick B, Gao V, Koo JW, Mazei-Robison MS, Dias C, Maze I, et al. 2012. $\mathrm{Racl}$ is essential in cocaine-induced structural plasticity of nucleus accumbens neurons. Nature Neurosci 15: 891-896.

Dobi A, Seabold GK, Christensen CH, Bock R, Alvarez VA. 2011. Cocaine-induced plasticity in the nucleus accumbens is cell specific and develops without prolonged withdrawal. J Neurosci 31: 1895-1904.

Dong Y, Green T, Saal D, Marie H, Neve R, Nestler EJ, Malenka RC. 2006. CREB modulates excitability of nucleus accumbens neurons. Nat Neurosci 9: 475-477.

Dumitriu D, Laplant Q, Grossman YS, Dias C, Janssen WG, Russo SJ, Morrison JH, Nestler EJ. 2012. Subregional, dendritic compartment, and spine subtype specificity in cocaine regulation of dendritic spines in the nucleus accumbens. J Neurosci 32: 6957-6966.

Etienne-Manneville S, Hall A. 2002. Rho GTPases in cell biology. Nature 420: 629-635.

Ferguson SM, Robinson TE. 2004. Amphetamine-evoked gene expression in striatopallidal neurons: Regulation by corticostriatal afferents and the ERK/MAPK signaling cascade. J Neurochem 91: 337-348.

Ferrario CR, Gorny G, Crombag HS, Li Y, Kolb B, Robinson TE. 2005. Neural and behavioral plasticity associated with the transition from controlled to escalated cocaine use. Biol Psychiatry 58: 751-759.

Festa ED, Russo SJ, Gazi FM, Niyomchai T, Kemen LM, Lin SN, Foltz R, Jenab S, Quinones-Jenab V. 2004. Sex differences in cocaine-induced behavioral responses, pharmacokinetics, and monoamine levels. Neuropharmacology 46: $672-687$.

Flores C, Wen X, Labelle-Dumais C, Kolb B. 2007. Chronic phencyclidine treatment increases dendritic spine density in prefrontal cortex and nucleus accumbens neurons. Synapse 61: 978-984.

Forlano PM, Woolley CS. 2010. Quantitative analysis of preand postsynaptic sex differences in the nucleus accumbens. J Comp Neurol 518: 1330-1348.

Georges F, Stinus L, Le Moine C. 2000. Mapping of $c$-fos gene expression in the brain during morphine dependence and precipitated withdrawal, and phenotypic identification of the striatal neurons involved. Eur J Neurosci 12: 4475-4486.

Gutierrez H, Davies AM. 2011. Regulation of neural process growth, elaboration and structural plasticity by NF-кB. Trends Neurosci 34: 316-325.

Hacker H, Karin M. 2006. Regulation and function of IKK and IKK-related kinases. Sci STKE 2006: re13.

Harris KM, Jensen FE, Tsao B. 1992. Three-dimensional structure of dendritic spines and synapses in rat hippocampus (CA1) at postnatal day 15 and adult ages: Implications for the maturation of synaptic physiology and long-term potentiation. J Neurosci 12: 2685-2705.

Heimer L, Zahm DS, Churchill L, Kalivas PW, Wohltmann C. 1991. Specificity in the projection patterns of accumbal core and shell in the rat. Neuroscience 41: 89-125.

Hollander JA, Im HI, Amelio AL, Kocerha J, Bali P, Lu Q, Willoughby D, Wahlestedt C, Conkright MD, Kenny PJ.
Psychostimulant-Induced Structural Plasticity

2010. Striatal microRNA controls cocaine intake through CREB signalling. Nature 466: 197-202.

Holtmaat A, Svoboda K. 2009. Experience-dependent structural synaptic plasticity in the mammalian brain. Nat Rev Neurosci 10: 647-658.

Holtmaat AJ, Trachtenberg JT, Wilbrecht L, Shepherd GM, Zhang X, Knott GW, Svoboda K. 2005. Transient and persistent dendritic spines in the neocortex in vivo. $\mathrm{Neu}$ ron 45: 279-291.

Hope B, Kosofsky B, Hyman SE, Nestler EJ. 1992. Regulation of immediate early gene expression and AP-1 binding in the rat nucleus accumbens by chronic cocaine. Proc Natl Acad Sci 89: 5764-5768.

Huang YH, Lin Y, Mu P, Lee BR, Brown TE, Wayman G, Marie H, Liu W, Yan Z, Sorg BA, et al. 2009. In vivo cocaine experience generates silent synapses. Neuron 63: $40-47$.

Hyman SE, Malenka RC. 2001. Addiction and the brain: The neurobiology of compulsion and its persistence. Nat Rev Neurosci 2: 695-703.

Hyman SE, Malenka RC, Nestler EJ. 2006. Neural mechanisms of addiction: The role of reward-related learning and memory. Annu Rev Neurosci 29: 565-598.

Im HI, Hollander JA, Bali P, Kenny PJ. 2010. MeCP2 controls BDNF expression and cocaine intake through homeostatic interactions with microRNA-212. Nat Neurosci 13: $1120-1127$.

Impey S, Davare M, Lasiek A, Fortin D, Ando H, Varlamova O, Obrietan K, Soderling TR, Goodman RH, Wayman GA. 2010. An activity-induced microRNA controls dendritic spine formation by regulating Rac1-PAK signaling. Mol Cell Neurosci 43: 146-156.

Johansson BB, Belichenko PV. 2002. Neuronal plasticity and dendritic spines: Effect of environmental enrichment on intact and postischemic rat brain. J Cereb Blood Flow Metab 22: 89-96.

Jongen-Relo AL, Groenewegen HJ, Voorn P. 1993. Evidence for a multi-compartmental histochemical organization of the nucleus accumbens in the rat. J Comp Neurol 337: $267-276$.

Jongen-Relo AL, Voorn P, Groenewegen HJ. 1994. Immunohistochemical characterization of the shell and core territories of the nucleus accumbens in the rat. Eur $J$ Neurosci 6: 1255-1264.

Kalivas PW. 2009. The glutamate homeostasis hypothesis of addiction. Nat Rev Neurosci 10: 561-572.

Kalivas PW, Lalumiere RT, Knackstedt L, Shen H. 2009. Glutamate transmission in addiction. Neuropharmacology 56: $169-173$.

Kauer JA, Malenka RC. 2007. Synaptic plasticity and addiction. Nat Rev Neurosci 8: 844-858.

Kawaguchi Y, Wilson CJ, Augood SJ, Emson PC. 1995. Striatal interneurones: Chemical, physiological and morphological characterization. Trends Neurosci 18: 527-535.

Kelz MB, Chen J, Carlezon WA Jr, Whisler K, Gilden L, Beckmann AM, Steffen C, Zhang YJ, Marotti L, Self DW, et al. 1999. Expression of the transcription factor $\Delta$ FosB in the brain controls sensitivity to cocaine. Nature 401: $272-276$ 
S.A. Golden and S.J. Russo

Kerchner GA, Nicoll RA. 2008. Silent synapses and the emergence of a postsynaptic mechanism for LTP. Nat Rev Neurosci 9: 813-825.

Kim Y, Sung JY, Ceglia I, Lee KW, Ahn JH, Halford JM, Kim AM, Kwak SP, Park JB, Ho Ryu S, et al. 2006. Phosphorylation of WAVE1 regulates actin polymerization and dendritic spine morphology. Nature 442: 814-817.

Kim WY, Shin SR, Kim S, Jeon S, Kim JH. 2009a. Cocaine regulates ezrin-radixin-moesin proteins and RhoA signaling in the nucleus accumbens. Neuroscience 163: 501-505.

Kim Y, Teylan MA, Baron M, Sands A, Nairn AC, Greengard P. 2009b. Methylphenidate-induced dendritic spine formation and $\triangle \mathrm{FosB}$ expression in nucleus accumbens. Proc Natl Acad Sci 106: 2915-2920.

Kim J, Park BH, Lee JH, Park SK, Kim JH. 2011. Cell typespecific alterations in the nucleus accumbens by repeated exposures to cocaine. Biol Psychiatry 69: 1026-1034.

Kiraly DD, Ma XM, Mazzone CM, Xin X, Mains RE, Eipper BA. 2010. Behavioral and morphological responses to cocaine require kalirin7. Biol Psychiatry 68: 249-255.

Koob GF, Le Moal M. 2005. Plasticity of reward neurocircuitry and the "dark side" of drug addiction. Nat Neurosci 8: $1442-1444$.

Kourrich S, Thomas MJ. 2009. Similar neurons, opposite adaptations: Psychostimulant experience differentially alters firing properties in accumbens core versus shell. J Neurosci 29: 12275-12283.

Kourrich S, Rothwell PE, Klug JR, Thomas MJ. 2007. Cocaine experience controls bidirectional synaptic plasticity in the nucleus accumbens. J Neurosci 27: 7921-7928.

Kumar A, Choi KH, Renthal W, Tsankova NM, Theobald DE, Truong HT, Russo SJ, Laplant Q, Sasaki TS, Whistler $\mathrm{KN}$, et al. 2005. Chromatin remodeling is a key mechanism underlying cocaine-induced plasticity in striatum. Neuron 48: 303-314.

LaPlant Q, Vialou V, Covington HE III, Dumitriu D, Feng J, Warren BL, Maze I, Dietz DM, Watts EL, Iniguez SD, et al. 2010. Dnmt3a regulates emotional behavior and spine plasticity in the nucleus accumbens. Nat Neurosci 13: 1137-1143.

Lee BR, Dong Y. 2011. Cocaine-induced metaplasticity in the nucleus accumbens: Silent synapse and beyond. Neuropharmacology 61: 1060-1069.

Lee KW, Kim Y, Kim AM, Helmin K, Nairn AC, Greengard P. 2006. Cocaine-induced dendritic spine formation in D1 and D2 dopamine receptor-containing medium spiny neurons in nucleus accumbens. Proc Natl Acad Sci 103: 3399-3404.

Le Moine C, Tison F, Bloch B. 1990. D2 dopamine receptor gene expression by cholinergic neurons in the rat striatum. Neurosci Lett 117: 248-252.

Lewis MH. 2004. Environmental complexity and central nervous system development and function. Ment Retard Dev Disabil Res Rev 10: 91-95.

Liao D, Hessler NA, Malinow R. 1995. Activation of postsynaptically silent synapses during pairing-induced LTP in CA1 region of hippocampal slice. Nature 375: $400-404$.
Linseman DA, Loucks FA. 2008. Diverse roles of Rho family GTPases in neuronal development, survival, and death. Front Biosci 13: 657-676.

Lobo MK, Nestler EJ. 2011. The striatal balancing act in drug addiction: Distinct roles of direct and indirect pathway medium spiny neurons. Front Neuroanat 5: 41.

Lobo MK, Covington HE III, Chaudhury D, Friedman AK, Sun H, Damez-Werno D, Dietz DM, Zaman S, Koo JW, Kennedy PJ, et al. 2010. Cell type-specific loss of BDNF signaling mimics optogenetic control of cocaine reward. Science 330: 385-390.

Lu L, Shepard JD, Hall FS, Shaham Y. 2003. Effect of environmental stressors on opiate and psychostimulant reinforcement, reinstatement and discrimination in rats: A review. Neurosci Biobehav Rev 27: 457-491.

Luo L. 2000. Rho GTPases in neuronal morphogenesis. Nat Rev Neurosci 1: 173-180.

Luscher C, Malenka RC. 2011. Drug-evoked synaptic plasticity in addiction: From molecular changes to circuit remodeling. Neuron 69: 650-663.

Lynch WJ, Carroll ME. 1999. Sex differences in the acquisition of intravenously self-administered cocaine and heroin in rats. Psychopharmacology (Berl) 144: 77-82.

Lynch WJ, Carroll ME. 2000. Reinstatement of cocaine selfadministration in rats: Sex differences. Psychopharmacology (Berl) 148: 196-200.

Ma XM, Wang Y, Ferraro F, Mains RE, Eipper BA. 2008. Kalirin-7 is an essential component of both shaft and spine excitatory synapses in hippocampal interneurons. J Neurosci 28: 711-724.

Mains RE, Kiraly DD, Eipper-Mains JE, Ma XM, Eipper BA. 2011. Kalrn promoter usage and isoform expression respond to chronic cocaine exposure. BMC Neurosci 12: 20.

Malenka RC, Bear MF. 2004. LTP and LTD: An embarrassment of riches. Neuron 44: 5-21.

Marie H, Morishita W, Yu X, Calakos N, Malenka RC. 2005. Generation of silent synapses by acute in vivo expression of CaMKIV and CREB. Neuron 45: 741-752.

Marinelli M, Piazza PV. 2002. Interaction between glucocorticoid hormones, stress and psychostimulant drugs. Eur J Neurosci 16: 387-394.

Matsuzaki M, Honkura N, Ellis-Davies GC, Kasai H. 2004. Structural basis of long-term potentiation in single dendritic spines. Nature 429: 761-766.

Maze I, Russo SJ. 2010. Transcriptional mechanisms: Underlying addiction-related structural plasticity. Mol Interv 10: $219-230$.

Maze I, Covington HE III, Dietz DM, LaPlant Q, Renthal W, Russo SJ, Mechanic M, Mouzon E, Neve RL, Haggarty SJ, et al. 2010. Essential role of the histone methyltransferase G9a in cocaine-induced plasticity. Science 327: 213-216.

Mazei-Robison MS, Koo JW, Friedman A, Lansink C, Robison AJ, Vinish M, Krishnan V, Kim S, Siuta M, Galli A, et al. 2011. Role for mTOR signaling and neuronal activity in morphine-induced adaptations in ventral tegmental area dopamine neurons. Neuron 72: 977-990.

McClung CA, Nestler EJ. 2003. Regulation of gene expression and cocaine reward by CREB and $\triangle$ FosB. Nat Neurosci 6: $1208-1215$.

McClung CA, Ulery PG, Perrotti LI, Zachariou V, Berton O, Nestler EJ. 2004. $\triangle$ FosB: A molecular switch for long- 
term adaptation in the brain. Brain Res Mol Brain Res 132: $146-154$.

McCutcheon JE, Wang X, Tseng KY, Wolf ME, Marinelli M. 2011. Calcium-permeable AMPA receptors are present in nucleus accumbens synapses after prolonged withdrawal from cocaine self-administration but not experimenteradministered cocaine. J Neurosci 31: 5737-5743.

Meffert MK, Chang JM, Wiltgen BJ, Fanselow MS, Baltimore D. 2003. NF- $\mathrm{B}$ functions in synaptic signaling and behavior. Nat Neurosci 6: 1072-1078.

Meyer DA, Richer E, Benkovic SA, Hayashi K, Kansy JW, Hale CF, Moy LY, Kim Y, O'Callaghan JP, Tsai LH, et al. 2008. Striatal dysregulation of Cdk5 alters locomotor responses to cocaine, motor learning, and dendritic morphology. Proc Natl Acad Sci 105: 18561-18566.

Murphy DD, Segal M. 1997. Morphological plasticity of dendritic spines in central neurons is mediated by activation of cAMP response element binding protein. Proc Natl Acad Sci 94: 1482-1487.

Nagerl UV, Eberhorn N, Cambridge SB, Bonhoeffer T. 2004 Bidirectional activity-dependent morphological plasticity in hippocampal neurons. Neuron 44: 759-767.

Nazarian A, Russo SJ, Festa ED, Kraish M, Quinones-Jenab V. 2004. The role of D1 and D2 receptors in the cocaine conditioned place preference of male and female rats. Brain Res Bull 63: 295-299.

Negishi M, Katoh H. 2005. Rho family GTPases and dendrite plasticity. Neuroscientist 11: 187-191.

Nestler EJ. 2001. Molecular neurobiology of addiction. Am J Addict 10: 201-217.

Nestler EJ. 2002. From neurobiology to treatment: Progress against addiction. Nat Neurosci 5: 1076-1079.

Nestler EJ. 2004. Molecular mechanisms of drug addiction. Neuropharmacology 47: 24-32.

Noguchi J, Matsuzaki M, Ellis-Davies GC, Kasai H. 2005. Spine-neck geometry determines NMDA receptor-dependent $\mathrm{Ca}^{2+}$ signaling in dendrites. Neuron 46: 609-622.

Norrholm SD, Bibb JA, Nestler EJ, Ouimet CC, Taylor JR, Greengard P. 2003. Cocaine-induced proliferation of dendritic spines in nucleus accumbens is dependent on the activity of cyclin-dependent kinase-5. Neuroscience 116: $19-22$.

O’Brien CP. 2008. Evidence-based treatments of addiction. Philos Trans R Soc Lond B Biol Sci 363: 3277-3286.

Ongur D, Price JL. 2000. The organization of networks within the orbital and medial prefrontal cortex of rats, monkeys and humans. Cereb Cortex 10: 206-219.

Penzes P, Cahill ME, Jones KA, VanLeeuwen JE, Woolfrey KM. 2011. Dendritic spine pathology in neuropsychiatric disorders. Nat Neurosci 14: 285-293.

Pickens CL, Airavaara M, Theberge F, Fanous S, Hope BT, Shaham Y. 2011. Neurobiology of the incubation of drug craving. Trends Neurosci 34: 411-420.

Pierce RC, Bell K, Duffy P, Kalivas PW. 1996. Repeated cocaine augments excitatory amino acid transmission in the nucleus accumbens only in rats having developed behavioral sensitization. J Neurosci 16: 1550-1560.

Pratt WE, Kelley AE. 2004. Nucleus accumbens acetylcholine regulates appetitive learning and motivation for food via activation of muscarinic receptors. Behav Neurosci 118: $730-739$.
Pratt WE, Spencer RC, Kelley AE. 2007. Muscarinic receptor antagonism of the nucleus accumbens core causes avoidance to flavor and spatial cues. Behav Neurosci 121: 1215-1223.

Pulipparacharuvil S, Renthal W, Hale CF, Taniguchi M, Xiao G, Kumar A, Russo SJ, Sikder D, Dewey CM, Davis MM, et al. 2008. Cocaine regulates MEF2 to control synaptic and behavioral plasticity. Neuron 59: 621-633.

Renthal W, Kumar A, Xiao G, Wilkinson M, Covington HE III, Maze I, Sikder D, Robison AJ, LaPlant Q, Dietz DM, et al. 2009. Genome-wide analysis of chromatin regulation by cocaine reveals a role for sirtuins. Neuron 62: 335-348.

Robinson TE, Kolb B. 1997. Persistent structural modifications in nucleus accumbens and refrontal cortex neurons produced by previous experience with amphetamine. $J$ Neurosci 17: 8491-8497.

Robinson TE, Kolb B. 1999. Morphine alters the structure of neurons in the nucleus accumbens and neocortex of rats. Synapse 33: 160-162.

Robinson TE, Kolb B. 2004. Structural plasticity associated with exposure to drugs of abuse. Neuropharmacology 47: $33-46$.

Robinson TE, Gorny G, Savage VR, Kolb B. 2002. Widespread but regionally specific effects of experimenterversus self-administered morphine on dendritic spines in the nucleus accumbens, hippocampus, and neocortex of adult rats. Synapse 46: 271-279.

Robison AJ, Nestler EJ. 2011. Transcriptional and epigenetic mechanisms of addiction. Nat Rev Neurosci 12: 623-637.

Rothenfluh A, Threlkeld RJ, Bainton RJ, Tsai LT, Lasek AW, Heberlein U. 2006. Distinct behavioral responses to ethanol are regulated by alternate RhoGAP18B isoforms. Cell 127: 199-211.

Russo SJ. 2008. The potential for viral gene therapy in psychiatry. Am J Psychiatry 165: 675.

Russo SJ, Festa ED, Fabian SJ, Gazi FM, Kraish M, Jenab S, Quinones-Jenab V. 2003a. Gonadal hormones differentially modulate cocaine-induced conditioned place preference in male and female rats. Neuroscience 120: $523-$ 533.

Russo SJ, Jenab S, Fabian SJ, Festa ED, Kemen LM, Quinones-Jenab V. 2003b. Sex differences in the conditioned rewarding effects of cocaine. Brain Res 970: 214-220.

Russo SJ, Bolanos CA, Theobald DE, DeCarolis NA, Renthal W, Kumar A, Winstanley CA, Renthal NE, Wiley MD, Self DW, et al. 2007. IRS2-Akt pathway in midbrain dopamine neurons regulates behavioral and cellular responses to opiates. Nat Neurosci 10: 93-99.

Russo SJ, Mazei-Robison MS, Ables JL, Nestler EJ. 2009a. Neurotrophic factors and structural plasticity in addiction. Neuropharmacology 56: 73-82.

Russo SJ, Wilkinson MB, Mazei-Robison MS, Dietz DM, Maze I, Krishnan V, Renthal W, Graham A, Birnbaum SG, Green TA, et al. 2009b. Nuclear factor $\kappa$ B signaling regulates neuronal morphology and cocaine reward. J Neurosci 29: 3529-3537.

Russo SJ, Dietz DM, Dumitriu D, Morrison JH, Malenka RC, Nestler EJ. 2010. The addicted synapse: Mechanisms of synaptic and structural plasticity in nucleus accumbens. Trends Neurosci 33: 267-276. 
S.A. Golden and S.J. Russo

Rymar VV, Sasseville R, Luk KC, Sadikot AF. 2004. Neurogenesis and stereological morphometry of calretininimmunoreactive GABAergic interneurons of the neostriatum. J Comp Neurol 469: 325-339.

Sarmiere PD, Bamburg JR. 2004. Regulation of the neuronal actin cytoskeleton by ADF/cofilin. J Neurobiol 58: 103-117.

Schiller MR, Ferraro F, Wang Y, Ma XM, McPherson CE Sobota JA, Schiller NI, Mains RE, Eipper BA. 2008. Autonomous functions for the Sec14p/spectrin-repeat region of Kalirin. Exp Cell Res 314: 2674-2691.

Schmidt H, Eilers J. 2009. Spine neck geometry determines spino-dendritic cross-talk in the presence of mobile endogenous calcium binding proteins. J Comput Neurosci 27: $229-243$.

Selemon LD, Begovic A, Goldman-Rakic PS, Castner SA. 2007. Amphetamine sensitization alters dendritic morphology in prefrontal cortical pyramidal neurons in the non-human primate. Neuropsychopharmacology 32:919_ 931.

Sell SL, Scalzitti JM, Thomas ML, Cunningham KA. 2000 Influence of ovarian hormones and estrous cycle on the behavioral response to cocaine in female rats. J Pharmacol Exp Ther 293: 879-886.

Shen HW, Toda S, Moussawi K, Bouknight A, Zahm DS, Kalivas PW. 2009. Altered dendritic spine plasticity in cocaine-withdrawn rats. J Neurosci 29: 2876-2884.

Singer BF, Tanabe LM, Gorny G, Jake-Matthews C, Li Y, Kolb B, Vezina P. 2009. Amphetamine-induced changes in dendritic morphology in rat forebrain correspond to associative drug conditioning rather than nonassociative drug sensitization. Biol Psychiatry 65: 835-840.

Sklair-Tavron L, Shi WX, Lane SB, Harris HW, Bunney BS, Nestler EJ. 1996. Chronic morphine induces visible changes in the morphology of mesolimbic dopamine neurons. Proc Natl Acad Sci 93: 11202-11207.

Sulzer D. 2011. How addictive drugs disrupt presynaptic dopamine neurotransmission. Neuron 69: 628-649.

Tada T, Sheng M. 2006. Molecular mechanisms of dendritic spine morphogenesis. Curr Opin Neurobiol 16: 95-101.

Taylor JR, Lynch WJ, Sanchez H, Olausson P, Nestler EJ, Bibb JA. 2007. Inhibition of Cdk5 in the nucleus accumbens enhances the locomotor-activating and incentivemotivational effects of cocaine. Proc Natl Acad Sci 104: 4147-4152.

Tepper JM, Tecuapetla F, Koos T, Ibanez-Sandoval O. 2010. Heterogeneity and diversity of striatal GABAergic interneurons. Front Neuroanat 4: 150.

Thomas MJ, Malenka RC. 2003. Synaptic plasticity in the mesolimbic dopamine system. Philos Trans $R$ Soc Lond B Biol Sci 358: 815-819.

Thomas MJ, Malenka RC, Bonci A. 2000. Modulation of long-term depression by dopamine in the mesolimbic system. J Neurosci 20: 5581-5586.

Thomas MJ, Beurrier C, Bonci A, Malenka RC. 2001. Longterm depression in the nucleus accumbens: A neural correlate of behavioral sensitization to cocaine. Nat Neurosci 4: $1217-1223$.
Thomas MJ, Kalivas PW, Shaham Y. 2008. Neuroplasticity in the mesolimbic dopamine system and cocaine addiction. Br J Pharmacol 154: 327-342.

Tolias KF, Duman JG, Um K. 2011. Control of synapse development and plasticity by Rho GTPase regulatory proteins. Prog Neurobiol 94: 133-148.

Ulery-Reynolds PG, Castillo MA, Vialou V, Russo SJ, Nestler EJ. 2009. Phosphorylation of $\Delta$ FosB mediates its stability in vivo. Neuroscience 158: $369-372$.

UNODC. 2010. World drug report. Sales No E.10.XI.13. United Nations Publications, New York.

Van den Oever MC, Spijker S, Smit AB, De Vries TJ. 2010. Prefrontal cortex plasticity mechanisms in drug seeking and relapse. Neurosci Biobehav Rev 35: 276-284.

Walker RJ, Brooks HL, Holden-Dye L. 1996. Evolution and overview of classical transmitter molecules and their receptors. Parasitology 113: S3-S33.

Wayman GA, Davare M, Ando H, Fortin D, Varlamova O, Cheng HY, Marks D, Obrietan K, Soderling TR, Goodman RH, et al. 2008. An activity-regulated microRNA controls dendritic plasticity by down-regulating p250GAP. Proc Natl Acad Sci 105: 9093-9098.

Wessell R, Edwards C. 2010. Biological and psychological interventions: Trends in substance use disorders intervention research. Addict Behav 35: 1083-1088.

Wissman AM, McCollum AF, Huang GZ, Nikrodhanond AA, Woolley CS. 2011. Sex differences and effects of cocaine on excitatory synapses in the nucleus accumbens. Neuropharmacology 61: 217-227.

Witten IB, Lin SC, Brodsky M, Prakash R, Diester I, Anikeeva P, Gradinaru V, Ramakrishnan C, Deisseroth K. 2010. Cholinergic interneurons control local circuit activity and cocaine conditioning. Science 330: 1677-1681.

Wolf ME. 2011. The Bermuda Triangle of cocaine-induced neuroadaptations. Trends Neurosci 33: 391-398.

Wolf ME, Tseng KY. 2012. Calcium-permeable AMPA receptors in the VTA and nucleus accumbens after cocaine exposure: When, how, and why? Front Mol Neurosci 5: 72.

Xi ZX, Baker DA, Shen H, Carson DS, Kalivas PW. 2002. Group II metabotropic glutamate receptors modulate extracellular glutamate in the nucleus accumbens. J Pharmacol Exp Ther 300: 162-171.

Xia Y, Portugal GS, Fakira AK, Melyan Z, Neve R, Lee HT, Russo SJ, Liu J, Morón JA. 2011. Hippocampal GluA1containing AMPA receptors mediate context-dependent sensitization to morphine. J Neurosci 31: 16279-16291.

XieZ, Srivastava DP, Photowala H, Kai L, Cahill ME, Woolfrey KM, Shum CY, Surmeier DJ, Penzes P. 2007. Kalirin-7 controls activity-dependent structural and functional plasticity of dendritic spines. Neuron 56: 640-656.

Zhang GC, Hoffmann J, Parelkar NK, Liu XY, Mao LM, Fibuch EE, Wang JQ. 2007. Cocaine increases Ras-guanine nucleotide-releasing factor 1 protein expression in the rat striatum in vivo. Neurosci Lett 427: 117-121.

Zuo Y, Lin A, Chang P, Gan WB. 2005. Development of longterm dendritic spine stability in diverse regions of cerebral cortex. Neuron 46: 181-189. 


\title{
$\&_{\mathrm{CSH}}^{\infty} \&$ Cold Spring Harbor \\ $\stackrel{\text { Perspectives }}{\longrightarrow \infty_{\infty}}$ Perspectives in Medicine
}

\section{Mechanisms of Psychostimulant-Induced Structural Plasticity}

\author{
Sam A. Golden and Scott J. Russo
}

Cold Spring Harb Perspect Med 2012; doi: 10.1101/cshperspect.a011957 originally published online August 30, 2012

\section{Subject Collection Addiction}

Developments from Bulk Optogenetics to Single-Cell Strategies to Dissect the Neural Circuits that Underlie Aberrant Motivational States Jose Rodriguez-Romaguera, Vijay M.K. Namboodiri, Marcus L. Basiri, et al.

Consequences of Parental Opioid Exposure on Neurophysiology, Behavior, and Health in the Next Generations

Fair M. Vassoler and Mathieu E. Wimmer

Animal Models of the Behavioral Symptoms of Substance Use Disorders Louk J.M.J. Vanderschuren and Serge H. Ahmed

Translational Research in Nicotine Addiction Miranda L. Fisher, James R. Pauly, Brett Froeliger, et al.

Neonatal Opioid Withdrawal Syndrome (NOWS): A Transgenerational Echo of the Opioid Crisis Andrew E. Weller, Richard C. Crist, Benjamin C. Reiner, et al.

Impairment of Synaptic Plasticity by Cannabis, $\Delta^{\mathbf{9}}$ -THC, and Synthetic Cannabinoids Alexander F. Hoffman, Eun-Kyung Hwang and Carl R. Lupica

Drug-Evoked Synaptic Plasticity of Excitatory Transmission in the Ventral Tegmental Area Camilla Bellone, Michael Loureiro and Christian Lüscher

Opioid-Induced Molecular and Cellular Plasticity of Ventral Tegmental Area Dopamine Neurons Marie A. Doyle and Michelle S. Mazei-Robison
The Persistent Challenge of Developing Addiction Pharmacotherapies

Sarah E. Swinford-Jackson, Charles P. O'Brien,

Paul J. Kenny, et al.

Opioid Modulation of the Gut-Brain Axis in Opioid-Associated Comorbidities

Li Zhang and Sabita Roy

Epigenetics of Drug Addiction Andrew F. Stewart, Sasha L. Fulton and lan Maze

Genetic Vulnerability to Opioid Addiction Brian Reed and Mary Jeanne Kreek

Glutamatergic Systems and Memory Mechanisms

Underlying Opioid Addiction Jasper A. Heinsbroek, Taco J. De Vries and Jamie Peters

Mechanisms of Nicotine Addiction Marina R. Picciotto and Paul J. Kenny

Neural Substrates and Circuits of Drug Addiction Matthew W. Feltenstein, Ronald E. See and Rita A. Fuchs

The Role of the Central Amygdala in Alcohol Dependence Marisa Roberto, Dean Kirson and Sophia Khom

For additional articles in this collection, see http://perspectivesinmedicine.cshlp.org/cgi/collection/ 